\title{
EXPULSION OF FOREIGNERS IN MEXICO: A COMMENTARY ON THE NEW "ADMINISTRATIVE PROCEDURE OF EXCLUSION" PROPOSED BY PRESIDENT ENRIQUE PEÑA NIETO UNDER THE REGLEMENTARY ACT OF ARTICLE 33 OF THE CONSTITUTION
}

Jorge A. Vargas ${ }^{1}$

\begin{abstract}
This study problematizes the expulsion of foreigners in México: a commentary on the New "Administrative Procedure of Exclusion" proposed by President Enrique Peña Nieto under the Reglementary Act of Article 33 of the Constitution. The Constitution of Mexico was profoundly influenced by the Constitution of the United States, and most of the "Individual guarantees" are derived from the U.S. Constitution. During the 19th and 20th centuries, Mexico was deferential to the use and philosophical meaning of the legal expression Garantías Individuales. This explains why Article 1 in Chapter I of the Constitution -formed by 29 articles- was titled: The Individual Guarantees. However, the long legal deference given to the term "Individual guarantees" was somewhat abandoned in 2011 when the then President of Mexico, Felipe Calderón Hinojosa, decided to change the name of Chapter I of the Constitution by means of a decree published in the Diario Oficial de la Federación (DOF) on June 10, 2011. This study shows how the multiple and complex intergovernmental regulatory networks relating to the mobility of this labor force developed in an international context, not solely within the development of isolated national legal systems. Therefore, it is of fundamental importance for Mexico to provide a fair and expeditious administrative procedure to expel, deport or extradite foreign persons; a procedure that clearly respects the human rights of foreigners in symmetry with the international standards that domestic legislation, international treaties and conventions, as well as the decisions that international courts have established on this important and delicate area. There is no doubt that the administrative procedure established by President Peña Nieto pursuant to the Reglementary Act o54f Article 33 of the Political Constitution may be characterized today as one of the most fair, modern and advanced procedures for the expulsion of foreign persons at the international level.
\end{abstract}

Keywords: Expulsion of foreigners. Mexico. Administrative Procedure of Exclusion. Reglementary Act of Article 33 of the Constitution. Human rights reform.

\footnotetext{
${ }^{1}$ Professor of Law at the University of San Diego School of Law. Summa cum laude, UNAM's School of Law; LL.M., Yale Law School and S.J.D. University of Virginia.E-mail: mexlaw@sandiego.edu.
} 


\section{INTRODUCTION}

The current Political Constitution of Mexico was formulated by a National Congress held at the City of Querétaro from November 16, 1916 to February 5, 1917, final date when this important document was formally promulgated. ${ }^{2}$ Adhering to a European format, Mexico's current constitution is composed by 136 articles, and Chapter I, Title I, titled: "Individual Guarantees," is referred to as the axiological part of this document. ${ }^{3}$ This chapter enunciates each of the numerous "Garantías Individuales" (Individual guarantees) described in the 29 articles of this chapter. These guarantees legally protect the fundamental rights of any person -whether a Mexican national, a refugee, a transient or a foreigner- who is physically present within the geographical boundaries of that country.

In Mexico, the concept of Garantías Individuales is understood to be a consecration of a given right. Accordingly, these guarantees refer to "those natural rights inherent to any human being that predate the State and are superior to it; rights which are not created by the State but are merely recognized and guaranteed by it." Positive law -and above all the Constitution-guarantees that these rights serve as the beginning and as the point of reference for the acts of the legislator and all the other public authorities." 5 Accordingly, these individual guarantees "generate legal consequences regarding their scope, nature and distinctions from other legal terms, including the procedural mechanisms for their defense."

In sum, whereas the "Rights of man" (Derechos del hombre) constitute an abstract and generic category, the Garantía individual "defines the individualized and concrete measure applied by the Constitution to protect

\footnotetext{
${ }^{2}$ See Felipe Tena Ramírez. Leyes Fundamentales de México, 1808-1999. Porrúa, México 1999 at 804-817. See also Javier Ferrer Mendiolea. Historia del Congreso Constituyente de 1916-1917. Instituto Nacional de Estudios Históricos de la Revolución Mexicana, 1957; Félix F. Palavicini. Historia de la Constitución de 1917. Vol. II, México; and Derechos del Pueblo Mexicano. México através de sus Constituciones, México, 1967. This part is characterized as a "Dogmatic part" because it contains the essential rights of any human being that may be opposed to the organs of the public power, as enunciated by Chapter I, Title I, of the constitution. The other part is the "Organic part" that establishes the organic structure of the government and their respective powers and functions; see Ariel Alberto Rojas Caballero. Las Garantías Individuales en México. Porrúa, México, 2009, Chap. 1 at pp.3-24.

${ }^{3}$ For a detailed discussion of "garantías individuales" within a constitutional law context, see Rojas Caballero, Ibid., Chap. 1 at pp. 324.

${ }^{4}$ Id.

${ }^{5} \mathrm{Id}$.

${ }^{6}$ Ibid. at 4-5.
} 
each of those [natural] rights." ${ }^{\text {T }}$ Semantically, Mexico's garantías individuales may also be referred to as fundamental rights or human rights. ${ }^{8}$

This profound respect for the rights of the individual is derived from the French Declaration of 1789 as part of that natural law trend that found its way into the text of many Latin American constitutions during the early $19^{\text {th }}$ century. The effective enjoyment of these rights is to be guaranteed by the State, as the promoter of social and economic development. Interestingly, most of the rights of man (Derechos del hombre) enunciated by the French declaration were incorporated almost verbatim into the Spanish Constitution of Cádiz of 1812, and it was from this solemn and lengthy document (containing 384 articles!) where said rights were taken from and then incorporated into a number of Latin American constitutions. ${ }^{10}$ In contrast, the Declaration of the Rights of the Good People of Virginia of 1776 did not include in its text the word "guarantee." 11

The Constitution of Mexico was profoundly influenced by the Constitution of the United States, and most of the "Individual guarantees" are derived from the U.S. Constitution. ${ }^{12}$ During the $19^{\text {th }}$ and $20^{\text {th }}$ centuries, Mexico was deferential to the use and philosophical meaning of the legal expression Garantías Individuales. 13 This explains why Article 1 in Chapter I of the Constitution -formed by 29 articles-- was titled: The Individual Guarantees. ${ }^{14}$ The first paragraph of article 1 of the 1917 Constitution reads:

\footnotetext{
${ }^{7}$ Id.

${ }^{8}$ For example, the Federal Constitution of 1857, an important and clear antecedent of the 1917 Political Constitution, titled the opening chapter I of this Constitution: "De los Derechos del Hombre" (Of the Rights of Man). For the text of articles 1 through 29, see Tena Ramírez, Leyes Fundamentales, pp. 607-611.

${ }^{9}$ For a detailed legal analysis of the presence of "Human rights" in the Constitution of Mexico, see Enrique Sánchez Bringas. los derechos humanos en la constitución y en los tratados internacionales. Porrúa, México (2001), Chap. 5 at 68-216.

${ }^{10}$ See James F. Smith. Introducción, Derecho Constitucional Comparado México-Estados Unidos. UNAM, México (1990), pp. $48-49$ et seq.

${ }^{11}$ See Victor Martínez Bullé, “La Declaración de los Derechos del Hombre y del Ciudadano de 1789," Bicentenario de la Revolución Francesa. México, UNAM (1991).

${ }^{12}$ See also Héctor Fix Zamudio. Algunos Aspectos de la Influencia del Constitucionalismo de los Estados Unidos en la Protección de los Derechos Humanos en el Ordenamiento Mexicano in Smith, supra note 9 at 133-163; Victor Niemeyer. El Congreso Constituyente norteamericano de 1787 y el Congreso Constituyente mexicano de 1916-1917. Comparación y Contraste in Smith, supra note 9 at 71-86. Even the official name of Mexico, i.e., Estados Unidos Mexicanos, was inspired by the name of the United States of America. (See the chart in Annex One comparing the Declaration of Rights found in the U.S. Constitution with the Individual Guarantees enunciated in the Mexican Constitution of 1917).

${ }^{13}$ See id.

${ }^{14}$ Historically, it is in the First Draft of the Constitution of 1842 when the expression "Garantías individuales" is used for the first time in a constitutional document. See Leyes Fundamentales, supra note 1 at 308. Article 7 of this Draft listed fifteen "Garantías individuales" to be "perpetually enjoyed by all the inhabitants of the Republic jointly with the natural rights of freedom, equality, security and property," (Paras. I-XV). Articles 8 to 10 of this Draft enunciated the rights and obligations of foreigners who should possess the corresponding "Letter of Security" (Carta de Seguridad) as prescribed by the laws." These "letters" were reputed as the pact or conditions under which foreigners were admitted into the Mexican society." See LEYES, supra 1 at 310.
} 
Every person in the United Mexican States (Estados Unidos Mexicanos) shall enjoy the guarantees granted by this Constitution, which cannot be restricted nor suspended except in such cases and under such conditions as are herein provided. ${ }^{15}$

However, the long legal deference given to the term "Individual guarantees" was somewhat abandoned in 2011 when the then President of Mexico, Felipe Calderón Hinojosa, decided to change the name of Chapter I of the Constitution by means of a decree published in the Diario Oficial de la Federación (DOF) on June 10, $2011{ }^{16}$ This decree, inter alia, substituted the traditional term of "Garantías Individuales" for the new concept of "Derechos Humanos." 17 The amended text of Article 1 of the Political Constitution today reads:

In the United Mexican States all persons shall enjoy the human rights recognized by this Constitution and by the international treaties to which the Mexican State is a party to, as well as the guarantees for their protection, whose exercise cannot be restricted nor suspended, save in the cases and under the conditions established by this Constitution.

The norms relative to human rights shall be interpreted in accordance with this Constitution and with the international treaties on this matter favoring persons at all time the most ample protection.

All the authorities, within the scope of their authority, shall have the obligation to promote, respect, protect and guarantee the human rights in accordance with the principles of universality, interdependence, indivisibility and progressivity. As a consequence, the State shall prevent, investigate, sanction and repair the violations to human rights in the terms established by the law.

Slavery is prohibited in the United Mexican States. Foreign slaves who enter the national territory will obtain, by this act alone, their liberty and the protection of the laws.

Discrimination is prohibited whether motivated by ethnic or national origin, gender, age, incapacities, social condition, health conditions, religion, opinions, sexual preferences, civil status or any other that may be against human dignity and have as its object to annul or undermine the rights and freedoms of persons. ${ }^{18}$

This constitutional reform - known as the "Human rights reform" - was not only welcomed but publicly celebrated throughout the country, especially in academic, legal, governmental and judicial circles. 19This

\footnotetext{
${ }^{15}$ Text taken from the Political Constitution of 1917, See Leyes, supra note 1 at 817 (All the English translations by the autor). In Mexico, the Diario Oficial plays a role similar to the Federal Register in the United States.

${ }^{16}$ Decreto por el que se Modifica la denominación del Capítulo I del Titulo Primero y reforma diversos artículos de la Constitución Política de los Estados Unidos Mexicanos (Decree that modifies the name of Chapter I, Title I and amends several articles of the Political Constitution of the United Mexican States, DOF of June 10, 2011). This decree entered into force the next day of its publication, namely June 11, 2011. The procedure to amend the Mexican Constitution is found in its Article 135 which adopted the system prescribed by Article IV of the U.S. Constitution requiring a two-third vote of the members of Congress and the approval of the amendments by a majority of the legislatures of the States. ${ }^{17}$ Id.

${ }^{18}$ The Spanish text is taken from Agenda de Amparo 2014. Editorial ISEF, México, D.F. (2014) at p. 1.
} 
amendment was considered to be among the most important revisions of the almost centenarian text of the 1917 Political Constitution. ${ }^{20}$ Inter alia, this reform accomplished several objectives:

1. It added to Mexico's constitutional language the modern concept of "human rights" taken from the international law area, ${ }^{21}$ thus abandoning the antiquarian notion of "Garantías individuales." As this reform mandates, "norms relative to human rights are to be interpreted in accordance with the constitution and with the applicable international treaties, favoring at all time the individual person with the most ample protection; ${ }^{22}$

2. At the domestic level, it established the supremacy of the international human rights treaties and conventions to which Mexico is a party, elevating them to a constitutional rank. The simple familiarity with the 47 international human rights instruments adhered to by Mexico until today constituted a welcome and didactic development especially for the benefit of Mexican judges (who tend to be rather unfamiliar with international law treaties and conventions); ${ }^{23}$

3. It led to the enactment of novel pieces of secondary legislation regarding: a) asylum; ${ }^{24}$ b) expulsion of foreigners (Art. 33); ${ }^{25} \mathrm{c}$ ) human rights victims' reparation; ${ }^{26} \mathrm{~d}$ ) temporary suspension of guarantees (Art. 29) $;{ }^{27}$ and e) the updating of the statute that created the National Commission on Human Rights $(\mathrm{CNDH}) ;^{28}$

4. The President of Mexico, as a part of his power to conduct the country's foreign policy in compliance with the mandated normative principles pursuant to article 89, para. X of the Constitution, shall conduct

\footnotetext{
${ }^{19}$ This reform generated an unprecedented and favorable wave of official and academic articles, commentaries and books. A sample follows: 1) M. Carbonell and P. Salazar. La Reforma Constitucional de Derechos Humanos. Porrúa/UNAM (2013); 2) Mtra. Claudia Gamboa Montejano and Lic. Arturo Ayala Cordero. Reforma Constitucional relativa a los Derechos Humanos y los Tratados Internacionales. LXI Legislatura, Cámara de Diputados. 3) Las Reformas Constitucionales en Materia de Derechos Humanos. Comisión de Derechos Humanos del Distrito Federal (2012); 4) Jorge Carpizo. Los derechos humanos: Una propuesta de clasificación de los derechos civiles y políticos. Revista de la Facultad de Derecho de México, Vol. 61, No. 256. 5) Carlos Castilla Juárez. Un nuevo panorama constitucional para el derecho internacional de los derechos humanos en México, Estudios Constitucionales. Año 9, No. 2, Universidad de Talca, 2011, pp. 123-164, etc.

${ }^{20} \mathrm{Id}$.

${ }^{21}$ See article 1 of the June 10,2011 decree.

${ }^{22}$ Today in Mexico this expansive interpretation of human rights always favoring the individual is commonly known now as the "Principio pro-persona." (Principle in favor of the person) choosing only those interpretations that are the most favorable to the person in resolving tensions or contradictions between human rights, jointly with the application of other principles such as "complementarity, interdependence and indivisibility." See "El Principio Pro-Persona" at La Reforma Constitucional sobre Derechos Humanos. Una Guía Conceptual by Pedro Salazar Ugarte, José Luis Caballero Ochoa and Luis Daniel Vázquez. Instituto Belisario Domínguez, Senado de la República, México, D.F., 2014, pp. 81-82.

${ }^{23}$ See First Transitory article.

${ }^{24}$ See First Transitory article.

${ }^{25}$ See Fifth Transitory article.

${ }^{26}$ See Second Transitory article.

${ }^{27}$ See Fourth Transitory article.

${ }^{28}$ See Eighth Transitory article.
} 
said foreign policy based upon "the respect, protection and promotion of human rights" and the quest in favor of peace and international security. ${ }^{29}$

5. A most important and unprecedented development in the human rights area was the deletion of the arbitrary and unfair legal language of Article 33 of the constitution that for ninety-four years (since the enactment of the Constitution in 1917) applied to the expulsion of foreigners in that country. Today, no foreigner is to be expelled from Mexico unless he/she defends his/her case at a hearing to be conducted -for the first time in the history of Mexico- under a special administrative procedure. ${ }^{30}$

This article examines the new and special administrative procedure that today governs the expulsion of foreigners in Mexico. This procedure includes the contributions made by international law and human rights to define and respect the rights of foreigners, as reflected in the new Reglementary Act of Article 33 of the Constitution, ${ }^{31}$ recently enacted by President Peña Nieto. 32The radical reform of the language of Article 33 was greatly facilitated by the "Human rights reform" made by President Calderon Hinojosa in his decree of June 10, 2011 that not only modified the name of Chapter I of the constitution but also introduced the notion of human rights throughout the constitutional text. ${ }^{33}$

\footnotetext{
${ }^{29}$ See Article 89 of the June 10, 2011 decree. In this regard, the Secretariat of Foreign Relations (SRE) launched a well-orchestrated international campaign to inform and promote the respect and protection of human rights as part of Mexico's foreign policy.

${ }^{30}$ The original text of Article 33, as enacted in 1917, read: "Foreigners are those who do not possess the qualifications set forth in Article 30. They are entitled to the guarantees granted by Chapter I, Title I, of the present Constitution; but the Federal Executive shall have the exclusive power to compel any foreigner, whose permanency he may deem inconvenient, to abandon the national territory immediately and without the necessity of previous legal action" (Emphasis added).

${ }^{31}$ The Fifth Transitory Article (Artículo Quinto Transitorio) of President Calderon's decree modifying the name of Chapter One of the Constitution cited in supra note 14, read: "The Congress of the Union shall enact the Reglementary Act of Article 33 of the Constitution, in matters of expulsion of foreigners (Ley Reglamentaria del Artículo 33 constitucional, en materia de expulsión de extranjeros) in a maximum term of one year counted from the initiation of the entry into force of this decree. Until said Reglementary Act is enacted, this article shall continue to be applied pursuant to the language of the current text."

${ }^{32}$ Id.

${ }^{33}$ La Reforma Constitucional de derechos Humanos," (The Constitutional Reform on Human Rights), Coordinated by Miguel Carbonell and Pedro Salazar. Porrúa-UNAM, Mexico, 2013 (nine extensive essays in 449 pp.) The constitutional reform proposed by President Calderon was published in the Diario Oficial de la Federación (DOF) on June 10, 2011. This book is a compilation of 13 essays written by Mexico's leading constitutional law authors, i.e., Miguel Carbonell, Pedro Salazar, Natalia Saltalamacchia, Ana Covarrubias, Jorge Carmona Tinoco, José Luis Caballero, Luis Vázquez, Sergio Garcia Ramirez, Jorge Carpizo, Catalina Pérez Correa, etc. addressing different angles of the reform proposed by President Calderon. For the text of the human rights incorporated into the Constitution of Mexico see the text of the decree published in the DOF on June 10, 2011. See also the book: La Reforma Constitucional sobre Derechos Humanos (The Constitutional Reform on Human Rights), coordinated by Pedro Salazar Ugarte and officially published by the Senado de la República (Instituto Belisario Dominguez). The purpose of this monumental work is to "enlarge and deepen the knowledge regarding one of the major and most relevant constitutional changes made to the Constitution during the second decade of the XXI century."

Prez Calderon human rights reform to the Constitution is considered to be a "reform that opens up a new paradigm in the constitutional law of Mexico," Presentation, p. xi.
} 


\section{CONSTITUTIONAL ANTECEDENTS OF ARTICLE 33}

Venustiano Carranza, head of the Constitutionalist Army in charge of the Executive Power in Mexico, reported that the Constitutional Congress meeting at the City of Querétaro approved the text of the Political Constitution on February 5, 1917, that entered into force on May 1, 1917. ${ }^{44}$ Article 33 of this Constitution read:

Article 33. Foreigners are those who do not possess the qualities set forth in article 30. They have the right to the guarantees granted in Chapter I, First Title, of the present Constitution; but the Executive of the Union shall have the exclusive power to make abandon the national territory, immediately and without the need of a previous hearing, of any foreigner whose permanency is deemed inconvenient. Foreigners may not, in any manner, become involved in the political matters of the country. ${ }^{35}$

Within the Latin American context, it is common to find provisions in the constitutional texts of countries in this region that define and separate foreigners vis-à-vis the nationals of a given country. ${ }^{36}$ However, none of these countries include such drastic and arbitrary provisions as those found in Article 33 of the Mexican Constitution.

This assertion is especially valid when Article 33 of the 1917 Constitution, as well as Article 1, expressly prescribe that the rights and protections granted by the individual guarantees (such as the right to due process and the right to a hearing found in Articles 14 and 16, respectively) are not limited to Mexicans but that they apply also "to any individual" -including foreigners - present in that country adding that "said guarantees cannot be restricted nor suspended but in the cases and under the conditions established by the Constitution." ${ }^{37}$

The key question is: what persuaded the Constitutional Congress of Querétaro to include such discriminatory and harsh language against foreigners in Article 33?

A review of the constitutional antecedents of Article 33 in previous constitutional texts clearly suggest an interesting trend: from a welcoming reception of foreigners to be reputed as Mexican citizens in the early times of the Mexican Republic (1811 to 1836), to a gradual exclusion, clear legal separation and unfair discrimination of foreigners in later constitutional pronouncements (1842 to 1916). ${ }^{38}$

\footnotetext{
${ }^{34}$ See First Transitory Article, Leyes, supra note 1 at 878.

${ }^{35} \mathrm{Ib}$. at 836 (Emphasis added).

${ }^{36}$ See, for example, the Constitutions of Argentina (Arts. 20 and 25); Bolivia (Art. 24); Colombia (Art. 100); Costa Rica (Arts. 19 and 34); Chile (Arts. 13 and 14); Ecuador (Arts. 14, 15 and 16); Honduras (Arts. 30-35); Uruguay (Art. 75); and Venezuela (Arts. 45,52 and 111), that include this type of provisions.

${ }^{37}$ The first paragraph of article 1 of the Mexican constitution today prescribes that "the human rights recognized in this constitution and in the international treaties to which the Mexican state is a party, as well as the guarantees for their protection ... shall apply to any person in the United Mexican States." See Constitución Política de los Estados Unidos Mexicanos in Agenda de Amparo 2104, editorial ISEF, p. 1

${ }^{38} \mathrm{All}$ of these antecedents are taken from Derechos, supra note 1 at 1072-1078.
} 
For example, in the Elementos Constitucionales enacted by Ignacio López Rayón in 1811, "Foreigners who favor freedom and the independence of the nation shall be received under the protection of the laws;" and in the later text of this same document published in 1814, "foreigners established in [Mexico] ...who profess the catholic religion are reputed to be Mexican citizens pursuant to the naturalization letter to be granted to them, enjoying the benefits of this enactment." ${ }^{39}$

In the Acta de Casa Mata (1823) "transient foreigners" were welcomed by the government, "protecting them in their persons and properties." ${ }^{40}$ Article 8 of the 1842 Draft Constitution is the first to define foreigners as those who do not possess the quality of Mexicans, imposing upon them a number of explicit obligations (i.e., respect the [Catholic] religion, comply with the judgments rendered by the tribunals (without the possibility of challenging them through legal means Mexican laws do not grant to Mexicans), and to cooperate to the expenditures of the State through the payment of taxes. ${ }^{41}$ Interestingly, this document obligated foreigners "to obtain and exhibit a so-called letter of security (Carta de seguridad) to be able to exercise the rights granted to them by the Constitution and by the laws." ${ }^{42}$

Article 38 of the Draft of a Political Constitution of 1856 recognized that, in addition to the rights granted to foreigners in Section I, Title I, foreigners shall also enjoy "the guarantees... emanating from the treaties [entered into by Mexico] with their respective nations." This document added that foreigners may "never file a claim against the [Mexican] nation but only when the government or other federal authority does not allow them to claim their rights in a legal manner, or oppose the implementation of a judgment rendered in accordance with the laws of the country." ${ }^{43}$

Article 33 of the 1857 Constitution is quite similar to the 1917 text, defining foreigners by exclusion. Unlike the arbitrary language found at the end of the current article, the final paragraph of this article read: "[Foreigners] have the obligation to contribute to public expenses in the manner prescribed by the laws, and to obey and respect the institutions, laws and authorities of the country, abiding by the awards and judgments of the courts, without interposing any other appeals than those granted by the laws to the Mexicans." ${ }^{44}$

Finally, the Draft of the 1917 Constitution formulated by Venustiano Carranza in 1916 appears to be drafted in harsher terms:

\footnotetext{
39 The "Elementos Constituciones" prepared by Lopez Rayon in August of 1811 is one of the very first documents intended to become a constitution for Mexico and it was composed by 38 articles. Article 20 prescribed; "any foreigner who wished to enjoy the privileges of an American citizen (sic) shall request from the Supreme Board a letter of naturalization to be granted by the municipal government (Ayuntamiento ) "See Ramirez, supra at 26.

${ }^{40}$ first draft, Political Constitution of the Mexican Republic (August 25, 1842) Id. At 309-310.

${ }^{41}$ Id.

${ }^{42}$ First Draft, Political Constitution of the Mexican Republic (August 25, 1842), Id. at 1075.

${ }^{43}$ Id. at 1077.

${ }^{44}$ Id. at 1078.
} 
Article 33 of the Draft: Foreigners are those who do not possess the qualities set forth by article 30 . They have the right to the guarantees granted by Section I, Title I, of the present Constitution; but the Executive of the Union shall have the exclusive faculty to make abandon the national territory immediately and without the need of a previous hearing (juicio previo), of any foreigner whose permanence is judged inconvenient. The determinations that the Executive may dictate in the use of this faculty shall have no recourse.

Foreigners may not, in any manner, become involved in the political matters of the country. Neither can they acquire real estate if they do not manifest previously, before the Secretariat of Foreign Relations, that they renounce to their quality of foreigners and to the protection of their governments in anything relating to those assets, being entirely subject, with respect to said assets, to the laws and authorities of the nation. ${ }^{45}$

The inclusion of discriminatory statements against foreigners in the Mexican constitutional texts started in middle of the 1850s and continued until 1916-1917. ${ }^{46}$ An explanation for this harsh treatment of foreigners may be associated with the fact that as soon as Mexico became an independent nation (1810-1821) this young republic started seeking international recognition and support from the international community. It was exposed to severe problems associated with emerging nations: no roads or transportation systems, lack of an educational system, rigid social casts, discrimination and separation of indigenous groups, political revolts, etc. but, above all, the lack of funds to improve and properly govern the country. ${ }^{47}$

The lack of capitals in an incipient national treasury led Mexico to seek financial support from a selected group of wealthy nations, such as Spain, ${ }^{48}$ France, ${ }^{49}$ the United Kingdom, ${ }^{50}$ Switzerland ${ }^{51}$, Germany, ${ }^{52}$ and the

\footnotetext{
${ }^{45}$ Ibid. This exception, subject to certain modifications, has remained in force until today and it is known now as "Convenio Artículo 27 Constitucional” (Special Agreement regarding Article 27, Paragraph One, of the Constitution). See Jorge A. Vargas. Fideicomisos: Real Estate Trusts in Mexico's Restricted Zone in Mexican Law: A Treatise for Legal Practitioners and International Investors, Vol. 1, pp.351-391 at 358.

46 This so-called "Letter of Security" (described in Article 13 of this Draft) was "reputed as a part or conditions under which foreigners are admitted into the Mexican Society" See Ramirez, supra at 309.

${ }^{47}$ For an excellent analysis of this topic, see Manuel Becerra Ramírez. El Artículo 33 Constitucional en el Siglo XXI. Biblioteca Jurídica Virtual del IIJ de la UNAM (2013) at 1635-1659; Beatriz Bernal. México y Cuba: Caminos Divergentes en materia de Expulsión de Extranjeros. Anuario Mexicano de Historia del derecho. México, UNAM, 1996, T. VIII at 17; and Cuauhtémoc de Dienheim Barriguete. El Artículo 33 de la Constitución y la Expulsión de Personas Extranjeras. IIJ/UNAM (2013) at 1635-1659.

${ }^{48}$ Spain did not recognize Mexico's independence in 1810 and started planning a reconquest of Mexico led by general Isidro Barradas in July of 1829 who surrendered in Tampico to general Antonio López de Santa Ana in October. This triggered a series of reprisals against the few remaining Spaniards in the country. The exodus of Spanish merchants further weakened Mexico's economy. See M. Meyer et al. The Course of Mexican History. Oxford University Press (1999) at 308.

${ }^{49}$ With the United States embroiled in its own civil war, Napoleon III, Emperor of France, decided to establish an empire in Mexico giving military support to Archduke Maximilian of Hapsburg (1864-1867) against the government of President Benito Juárez. President Lincoln supported Juárez based on the "Monroe Doctrine" that predicated that the Americas were off limits to European Colonization. The United States advised the French to leave and Napoleon recalled his troops in late 1866.

${ }^{50}$ See McKenzie Johnstone, Henry. Mission to Mexico: A Tale of British Diplomacy in the 1820's. New York: Saint Martin Press, 1992.

${ }^{51}$ Based on the Constitution of 1824, Mexico, as a new republic was faced with a "total lack of financial resources" and the political necessity of obtain the recognition of the major powers, the Vatican, the United States, Spain, France, the United Kingdom, and Germany. In 1822 only the United States, Chile, Colombia and Peru recognized Mexico's independence and Joel R Poinsett
} 
United States. ${ }^{53}$ The credits negotiated with these nations, consisting of large monetary sums subject to prohibitive interest, became complicated when Mexico - permanently affected by domestic political problems, internal revolutions, constant changes of governments, and a chronic lack of funds in the national treasury- was unable to pay most of these credits. ${ }^{54}$ The foreign agents of powerful financial and military nations involved in the negotiation of credits charged large sums as "commissions," and if the credit or their commission was not paid they threatened to involve their powerful countries to collect the money by any means, including military force. ${ }^{55}$ At the same time, said agents requested a special and privileged legal treatment to collect their loans that departed from the standard legal means sanctioned by the Mexican legal system. ${ }^{56}$

Most of these foreign nations were not only prepared but were already in fact planning to negotiate the payment of their credits by acquiring vast portions of the territory of this young and weak republic. ${ }^{57}$ Although Spain and France ${ }^{58}$ attempted to obtain Mexican territories, it was the United States of America the country that became the most ambitious in acquiring the largest portions of this relatively young, militarily weak and contiguous country. The United States orchestrated a secret plan to acquire Texas, ${ }^{59}$ first lending it its support for this vast Mexican territory to become a "Republic" in 1836 and then to welcome this "republic" into the United States. ${ }^{60}$

Mexico's situation at that time was critical threatened by both the United States and Spain, who had orchestrated a conspiracy to install a monarchical system in Mexico, in a plan secretly supported by France and the United Kingdom. ${ }^{61}$

arrived at Mexico City in 1825. British loans allowed the government led by President Guadalupe Victoria to be able to function for a few years. Other loans were extended by Spain, France, Switzerland and the United States. See Josefina Zoraida Vázquz, El Establecimiento de México Independiente(1821-1848), Historia de México 163-168 (Girseda Von Wohser Ed. 2010)

${ }^{52}$ See id.

${ }^{53}$ See id.

${ }^{54}$ See id.

${ }^{55}$ See id. In 1832, general Antonio Lopez de Santa Ana made a war pronouncement and was extended throughout the country as reported by Vázquez, supra, at 170 .

${ }^{56}$ See id. As soon as Mexico became independent, the Mexican government gave generous incentives to populate the Mexican provincles in the North, especially Texas and California. The Colonization Act of 1830 led to the "colonization" of those ter ritories by thousands of Americans who declared the idependence of Texas on March 6, 1836. According to Zoraida Vazques the national and internation conflictis were adverse to Mexico who was threated by the United States and Spain, interested in establishing a monarchial government in that country, with the support of France and the United Kingdom. Josefina Zorida Vázques, De la Independencia

${ }^{57}$ For a detailed narrative as to how the vast province of Texas first separated from Mexico and then accepted the offer by President Andrew Jackson to join the United State, See Vázquez" supra 12 at 171-173

${ }^{58}$ See William S. Robertson. French Intervention in Mexico in 1838. HispaniC AMERICAN HisTORICAL ReVIEW 24 (1944) at $222-$ 252.

${ }^{59}$ Meyer, supra note 35, The Loss of Texas and the War with the United States 323-341.

${ }^{60}$ See Josefina Zoraida Vázquez. De la Independencia a la Consolidación Republicana (From the Independence to the Republican Consolidation) in Nueva Historia Mínima de MéxiCo. El Colegio de México (2004), pp. 158-164.

${ }^{61}$ Ibid. at 163-164. 
After having acquired Texas and Sonora, the United States declared war against Mexico and then proceeded to militarily invade this country. ${ }^{62}$ The U.S. Army disembarked at the port of Veracruz, in the Gulf of Mexico, and on September 14, 1847, the American flag was flying at Mexico City's national palace. ${ }^{63}$ The expansionist furor in Washington, D.C., fueled by the successive military victories of the U.S. Army was so intense at that time that many were asking President Polk that the United States should annex the entire country! ${ }^{64}$

After defeating the Mexican Army, in 1848 the U.S. Army occupied Mexico City. By means of the Treaty of Guadalupe Hidalgo, signed on February 2, 1848, the United States acquired one of the largest and richest portions of Mexico's territory, ${ }^{65}$ including New Mexico and Alta California; in addition, the new international boundary was pushed south to reduce Mexico's vast territories of Tamaulipas, Sonora and Baja California. ${ }^{66}$

It should not be surprising to read that, at that time, the Colonization Act (dating back to 1824) limited the acquisition of real estate by foreigners in border and coastal areas. ${ }^{67}$ According to this federal statute, foreigners required prior approval from the office of the President of the Republic to acquire real estate. ${ }^{68}$ Today, Article 27, para. I, of Mexico's Political Constitution has retained some of the language found in the 1824 text. The current constitutional text reads:

1. Only Mexicans by birth or by naturalization and Mexican companies (with no foreign investment) have the right to acquire the direct ownership (dominio directo) of lands, waters and their accessions or to obtain concessions for the exploitation of mines and waters. The State may grant the same right to foreigners, provided they agree before the Secretariat of Foreign Relations to be considered as [Mexican]

\footnotetext{
${ }^{62}$ For an overview of the U.S.- Mexico war, See Vázquez, supra note 41 and Complication of the Messages and Papers of Presidents 1789-1908 at supra nota 44. See Also, Vázquez supra 18 at 173.

${ }^{63}$ For an overview of the U.S.- Mexico war, See Vázquez, supra note 41 and Complication of the Messages and Papers of Presidents 1789-1908 at supra nota 44. See Also, Vázquez supra 18 at 173.

${ }^{64}$ Id. at 166. During the presidency of Bustamante the French Ministries gave Mexico an ultimatum from the port of Veracruz, already occupied by the French Navy to pay the claims advance by French nationals living in Mexico or these ports would be blocked by the French Navy. After a year of a blockage and bombardments Mexico negotiated an international load to pay France, and thus restore the peace. See Vázquez, supra 18 at pp. 173-175. For additional information see Meyer, supra at 300-350,

${ }^{65}$ In a message to Congress to report the end of the "War of Conquest" against Mexico, President Polk proudly estimated that the newly acquired territory totaled over 851,598 square miles. See President James K. Polk's Fourth Annual Message to Congress, December 5, 1848. Compilation of the Messages and Papers of the Presidents, 1798-1908, 2483-2484. The United States gave Mexico \$15 million dollars "in consideration of the extension acquired... by the United States." According to Zorrilla, the territories lost by Mexico totaled some two million hectares, equivalent to more than half of Mexico's territory! See Luis G. Zorrilla. Historia de las Relaciones entre Mexico y los Estados Unidos de América, 1800-1958, at 227 (1977).

${ }^{66}$ See Historia General de México. El Colegio de México 2000 at pp. 570-582 and 585-595. See also Jorge A. Vargas. Is the International Boundary between the United States and Mexico Wrongly Demarcated? 30 California Western International Law Journal (Spring 2000, No. 2) at 215-275. Zorrilla points out that "one generation prior to the 1848 Treaty the "United States used to sell the lands which it had obtained from the Indians at no less than $\$ 1.25$ per acre, which is close to $\$ 3.00$ dollars per hectare. Based on this calculation, the sum the United States should have paid Mexico was in the order of over half a billion dollars!" See Vargas, supra at 253 .

${ }^{67}$ See Ramirez, supra at 309-310. See also Meyer, supra 323-341, Richard Griswold del Castillo, The Treaty of Guadalupe Hildalgo (1990), David M Pletcher, The Diplomacy of Annexation: Texas, Oregon and the Mexican War (1973)

${ }^{68}$ See Jorge A. Vargas. Fideicomisos, supra note 33 at pp.362-364.
} 
nationals with respect to said assets and to not invoke the protection of their governments regarding same; under penalty, in case of breaching this agreement, of losing said assets for the benefit of the Nation.

In a belt of one hundred kilometers along the borders and fifty kilometers along the beaches, no foreigner may acquire under any circumstances the direct ownership over lands and waters. ${ }^{69}$

During his dictatorship, Porfirio Díaz opened the doors of Mexico to foreigners and to foreign investment from the U.K. (whose engineers designed and built Mexico's railroad system); France, who controlled the textile industries in Puebla, Veracruz and Tlaxcala; and the United States who had thousands of Americans who possessed agricultural lands and ranches in the rich lands of Veracruz; mines in Tlaxcala and Zacatecas; vast extensions for cattle in Nuevo León and Chihuahua, and rich oil industry fields in Veracruz and in other coastal States bordering the Gulf of Mexico. ${ }^{70}$ So, when a violent revolution started in Mexico in 1910 to end the Díaz dictatorship and establish a democratic government, President Taft was deeply concerned with the economic interests of Americans in that country. ${ }^{71}$

The American ambassador to Mexico at that time, Henry Lane Wilson, convinced President Taft to prepare the Army and the Navy to intervene in Mexico to protect the lives and economic interests of Americans in that country. ${ }^{72}$ Eventually, U.S. Navy warships arrived at several ports in the Gulf of Mexico, and the Fifth Brigade of the U.S. Army quickly moved to Galveston, Texas, ready to intervene in Mexico if necessary.73

The publication of the 1917 Constitution and the text of Article 27 added another complication to the already politically difficult and tenuous relations between the U.S. and Mexico at that time. Article 27 of the new Constitution nationalized the oil and the mining industries! This article prescribed:

Article 27. Ownership of the lands and waters comprised within the boundaries of the national territory is vested originally in the Nation that has had, and has, the right to transmit their ownership to particular persons, thereby constituting private property.

69Art. 27, para. I, Political Constitution of the United Mexican States. See also Jorge A. Vargas. Acquisition of Real Estate. Mexican Law for the American Lawyer (Carolina Academic Press), (2009) at 155-187. See the text of footnote 34 regarding the Special Agreement (Convenio Artículo 27 Constitucional) foreigners must enter into today to be able to possess assets in the so-called "Restricted Zone" located in border and coastal areas.

${ }^{70}$ The economic transformation of Mexico during the presidency of Porfinio Diaz was due to the economic genius of Jose Limantour, Secretary of the Treasury. This official applied his skills to the reogranziation of the treasury and Mexico met its foreign obligations on a regular basis', diplomatic relations were opened with all of Europe and new treaties of friendship, commerce and with Great Britain, France, Norway, Ecuador, and Japan. For the first time Mexico began to participate actively in international conferences and foreign heads of states were lavish in their praise of the Diaz regime. By the late 1880's Diaz had began to receive medals and decorations from foreign governments. Taken from Meyer, supra at 427. See also, Elisa Speckman Guerra, El Porfirato, Nueva Historia minima de México 192 (2004).

${ }^{71}$ John S.P. Eisenhower, Intervention! The United States and The Mexican Revolution 1913-1917, 22

${ }^{72}$ See Berta Ulloa. La Lucha Armada (1911-1920). Historia General de México (Versión 2000). El Colegio de México at 765

${ }^{73}$ See Id. See also Historia de México (Coordinación de Gisela Von Wobeser). FCE/SEP (2010), El Porfiriato (1876-1911) and Los Años Revolucionarios (1910-1934) at 209-225 and 227-248. 
Expropriations may only be for cause or public utility, and by means of indemnification. The Nation has direct ownership of all minerals or substances that are in veins, layers, or masses; or beds of ore that constitute deposits naturally distinct from the components of the earth, such as minerals; ...of petroleum and all solid, liquid or gaseous hydrocarbons.

In the cases referred to in the two paragraphs above, the ownership of the Nation is inalienable and cannot prescribe (imprescriptible) and only the Federal Government may make concessions to be granted to particular persons or civil or commercial societies established according to Mexican laws under the condition that regular works for the exploitation of the resources are to be conducted in compliance with the requirements prescribed by the laws. With respect to oil and other solid, liquid and gaseous hydrocarbons, no concessions shall be issued and the corresponding Regulatory Act (Ley Reglamentaria) shall determine the form in which the Nation shall conduct the exploitation of said products. ${ }^{74}$

At that time (1916-17), the oil industry in Mexico was controlled by foreign companies from the United States, the United Kingdom, The Netherlands and France. The boom of the U.S. oil industry, especially in Texas, quickly spilled over to the Gulf of Mexico coasts. ${ }^{75}$ U.S. and British firms dominated the emerging Mexican oil industry from the start. ${ }^{76}$ Oil pioneers such as Henry Clay Pierce of the United States and Sir Weetman Pearson of the U.K. controlled the emerging Mexican oil industry from the start. ${ }^{77}$

Pierce and Pearson began as sellers of oil products rather than producers. ${ }^{78}$ Pierce -allied with John D. Rockefeller's Standard Oil- imported crude oil from the United States and processed it at three Mexican refineries and sold the products in Mexico. ${ }^{79}$ The most important problem for the oil companies was the government reliance on the oil industry as a source of taxes. With the Mexican economy in shambles a booming industry was a tempting source of revenue for the Mexican government. ${ }^{80}$

Foreign control of this important industry became an extremely controversial issue in a country that had become highly nationalistic. ${ }^{81}$ To complicate this question, managerial, technical and skilled labor positions were reserved to foreign engineers and this led to a discriminatory policy against Mexican workers. ${ }^{82}$ When foreigners and Mexican workers performed the same jobs, foreigners were preferred and received better pay. ${ }^{83}$ In addition,

\footnotetext{
${ }^{74}$ The text of Article 27 in the 1917 Constitution was taken from Leyes, supra note 1 at 825-827.

${ }^{75}$ For a general overview of this industry at that time, see Don M. Coerver, S. Pasztor and R, Buffington. Mexico. An Encyclopedia of Contemporary Culture and History, Oil Industry at 352-357

${ }^{76} \mathrm{Id}$.

${ }^{77} \mathrm{Id}$.

${ }^{78} \mathrm{Id}$.

${ }^{79} \mathrm{Id}$.

${ }^{80} \mathrm{Id}$.

${ }^{81}$ Id. at 353

${ }^{82}$ Id.

${ }^{83}$ Id.
} 
foreign companies strongly opposed the formation of unions. ${ }^{84}$ To complicate matters further, the enactment of the new 1917 Constitution and the text of Article 27, predicating that the Mexican nation had the "direct ownership of all minerals and substances that are in veins, layers or masses; or beds of ore that constitute deposits... such as minerals; of petroleum and all solid, liquid or gaseous hydrocarbons" 85led to direct confrontations between the oil foreign companies and the Mexican government, with the corresponding devastating economic impact upon all foreign companies. Whereas the oil production reached 193 million barrels in 1921, by the end of the decade, production had slid to 40 million barrels, and prices dropped almost 50\% between 1920 and $1921 !^{86}$

The tense situation between the foreign oil companies and the Mexican government reached a critical point with the election of President Lázaro Cárdenas in 1934. ${ }^{87}$ Instead of allowing the existing fragmentation of the oil unions (that totaled 21 different small unions) President Cárdenas strongly encouraged the formation of one major industry-wide union thinking that this giant union would be more effective to confront and negotiate with the powerful large multinational companies that dominated the oil business. ${ }^{88}$ Encouraged with the political support given to them by President Cárdenas, the new union demanded a pay raise, equal treatment for Mexican workers and greater control over management and supervisory positions. ${ }^{89}$

Not unexpectedly, the foreign companies strongly opposed these claims and took the case to Mexican labor courts. ${ }^{90}$ The Mexican Supreme Court ruled in favor of the Mexican workers on December 2, 193991 and then the oil companies, in a defying act, refused to abide by this final and definite judgment, thus provoking a national crisis! ${ }^{92}$ Forced by these prepotent acts, President Cárdenas on March 18, 1938 issued a decree nationalizing the foreign-oil companies that accounted for more than $90 \%$ of Mexico's total oil production! ${ }^{13}$

Mexican history clearly illustrates the constant and recurring problems created by a selected number of foreign nations, and their nationals, that threatened the very existence of this country for a long time. These

\footnotetext{
${ }^{84} \mathrm{Id}$.

${ }^{85}$ Ramírez, Supra at 826

${ }^{86}$ Ibid. at 355 .

${ }^{87}$ id. at 354

88 id.

${ }^{89}$ Id. at $353-355$.

${ }^{90} \mathrm{id}$.

91 id.

92 id,

${ }^{93}$ Considering that this case attracted global attention, the government of Mexico published a pamphlet explaining the legal and economic aspects of the case and the decision rendered by Mexico's Supreme Court. See The True Facts about the Expropriation of the Oil Companies' Properties in Mexico. Government of Mexico, Mexico City, 1940.
} 
problems appeared since the time Mexico acquired its political independence dating back to 1810 and continued until 1938, when President Lázaro Cárdenas nationalized the powerful foreign oil industries. ${ }^{94}$

With less than half of the geographical territory Mexico originally possessed when it became a politically independent nation in 1810, today this country may consider that the legal provisions found in its different constitutional documents, codes and statutes regulating the acts of foreigners in that country -such as Articles 27 and 33 of the current 1917 Constitution, for example- may have contributed to provide some legal protection or a deterrent against the arbitrary acts displayed in the past against Mexico by certain foreign nations and their nationals.

Undoubtedly, the closer and more friendly relations Mexico continues to foster with the United States ${ }^{95}$ (and with other key countries); the entering of treaties on foreign investment as well as trade and commerce (such as NAFTA and GATT, for example); and the respect and full compliance given by Mexican authorities to human rights, no doubt will contribute to eliminate the discriminatory language against foreigners present today in Mexico's constitutional text, as well as in the legal language in certain codes, statutes and regulations. ${ }^{96}$

\section{THE NEW REGLEMENTARY ACT OF ARTICLE 33 OF 2014}

Rather than including a balanced legal text that enunciates -in a legal and objective manner- the rights foreigners enjoy while visiting, investing or doing business in that country, the language used by the 1916-1917 Constitutional Congress appears to be not only arbitrary but almost threatening to foreigners.

As expressed by Dr. Manuel Becerra Ramírez in a recent article, the "model of expulsion adopted by Mexico responds to a historical moment determined by the strong threats from abroad imposed upon to a young Mexican state. ${ }^{, 97}$ In other words, the ample powers conferred to the Executive by the Constitution in 1917 can be easily explained when one equates these powers to those derived from an "imperial presidency," i.e., an Executive

\footnotetext{
${ }^{94}$ See also Roscoe B. Gaither. Expropriation in Mexico: The Facts and the Law (NY: William Morrow and Co., 1940); Lorenzo Meyer. Mexico and the United States in the Oil Controversy, 1918-1942 (Austin, U. Texas Press) 1972; and Catherine E. Jayne. Oil, War and Anglo-American Relations. Greenwood Press (2001).

${ }^{95}$ For a review of some of the current issues associated with Mexico's foreign affairs, see Guadalupe Gonzáez and Olga Pellicer. LA POlítica EXTERIOR DE MÉXICO . Itam-Siglo XXI, 2013.

${ }^{96}$ For an excellent overview of key topics in today's international foreign affairs agenda of Mexico, see LA POLíTICA EXTERIOR DE MÉXICO. Metas y Obstáculos by Guadalupe González and Olga Pellicer. ITAM/Siglo XXI Editores (2013); and P. Smith and A. Selee (Eds.)MeXico And THE United STATES (Lynne Rienner Publishers) 2013.

${ }^{97}$ See Manuel Becerra Ramírez. Article 33 in the $21{ }^{\text {st }}$ Century. Revista Legal del Instituto de Investigaciones Jurídicas de la UNAM, pp.60-83. See also Javier Wimer. El Artículo 33 Constitucional. Comisión Mexicana de Defensa y Promoción de los Derechos Humanos, No. 2, pp. 1-2 and 35-37; Nuria González. Comentario al Artículo 33, Constitución Política (Comentada y Concordada). 18 ${ }^{\text {th }}$ ed., México 2004, Tomo II; and Cuauhtémoc Dedienheim, El Artículo 33 y la Expulsión de Personas Extranjeras. IIJ, UNAM, 26 pp.
} 
with virtually unlimited powers that led into multiple injustices and whose existence today clearly clashes with the new model and legal philosophy of human rights..$^{98}$

Historically, Mexico suffered dictatorial regimes dating back to Santa Ana in 1823 until 1855 and Porfirio Díaz in the late $19^{\text {th }}$ century until 1910, when the violent eruption of the Mexican revolution forced him to leave the country and seek his self-imposed exile in Paris. ${ }^{99}$ During the $20^{\text {th }}$ century, some Mexican presidents distinguished themselves for their intense nationalism, among them Venustiano Carranza and Lázaro Cárdenas. Moreover, in Mexico the President of the Republic enjoys not only the specific powers enunciated by the Political Constitution, ${ }^{100}$ but also many other assumed, yet undefined, powers that have been known as "Metaconstitutional" (i.e., powers that derive not from the constitutional text but from historical events, custom, political concessions, etc. $)^{101}$

In numerous decisions rendered by the Supreme Court of that country, it is clearly accepted -without any reservations- the unilateral and "discretional" power of the President of the Republic to expel foreigners, as indicated by these decisions:

Based on Article 33 of the Constitution, the President of the Republic is endowed with the exclusive and discretional power to make abandon the national territory, immediately and without the need of a previous hearing, of any foreigner whose permanence is judged inconvenient; and against the exercise of these powers to grant a suspension [of the act offending a foreigner] is not to be granted. (Semanario Judicial de la Federación, Quinta época, T. ix, p. 409);

The provision of Article 33, granting the power to the President of the Republic to expel, immediately and without the need of a previous hearing, any foreigner deemed to be pernicious, is so categorical, that it does not admit any other interpretation ${ }^{102}$.

Even though Article 33 of the Constitution confers the Executive the power to make abandon the national territory to foreigners whose permanency is deemed inconvenient, this does not mean that said foreigners are to be deprived of their right to enjoy the constitutional guarantees granted in Chapter I, Title I, of the Constitution; consequently, the order of expulsion (to be issued by the Executive Power) must be well founded, explained and issued [debe ser fundada, motivada y despachada] through the proper legal norms and channels ${ }^{103}$.

\footnotetext{
${ }^{98}$ Becerra, supra 57, Ibid.

${ }^{99}$ See Meyer, supra at 312;488

${ }^{100}$ Chapter III of Mexico's Constitution, formed by articles 80 to 90, enunciates the powers and obligations of the Executive Power.

101 Fernando Serrano Migalión, Meta-Constutional Powers of the Executive Branch In Mexico, 2;3 http://www.law.yale.edu/documents/pdf/Meta_Constitutional_Powers.pdf

${ }^{102}$ Semanario Judicial de la Federación, Quinta época, T. Iv, p. 323).

${ }^{103}$ (Semanario Judicial de la Federación, Quinta época, t. cx, p. 113)
} 
Although it is true that Article 33 of the Constitution prescribes that foreigners have the right to the [Individual] guarantees granted by the Federal Constitution, it is also true that both foreigners and nationals are obligated to comply with the laws of the country, without implying that such compliance constitutes a violation of said guarantees, since same Article 33 broadly empowers the Executive of the Union to make abandon the national territory of any foreigner whose permanency is judged inconvenient, and undoubtedly this includes the reticence to comply with said laws ${ }^{104}$.

\section{First amendment to Articles 1 and 33 of the Political Constitution}

Although the Political Constitution of Mexico has been amended some 500 times since its promulgation in 1917, the original text of Articles 1 and 33 had remained untouched for almost a century until they were revised by the recent decree of June 10, 2011. ${ }^{105}$ President Calderon realized that for a "Human rights reform" to succeed it was simply indispensable to drastically reform and modernize the arbitrary and unfair language used by Articles 1 and 33. ${ }^{106}$ The revised and current texts of Articles 1 and 33 of the Constitution today read:

Article 1. In the United Mexican States all persons shall enjoy the human rights recognized in this Constitution and in the international treaties to which the Mexican State is a party, as well as the guarantees for their protection, whose exercise cannot be restricted nor suspended, save in the cases and under the conditions established by this Constitution.

The norms relative to human rights are to be interpreted in accordance with this Constitution and with the international treaties on this subject favoring persons the most ample protection at all times.

All the authorities, within the scope of their competence, shall have the obligation to promote, respect, protect and guarantee human rights in accordance with the principles of universality, interdependence, indivisibility and progressivity. As a consequence, the State shall prevent, investigate, sanction and repair the violations to human rights, in the terms established by the law.

It is prohibited any discrimination motivated by ethnic or national origin, gender, age, incapacities, social condition, health conditions, religion, opinions, sexual preferences, civil status or any other that offends the human dignity and whose object is to annul or undermine the rights and freedoms of persons.

\footnotetext{
${ }^{104}$ These judicial decisions were taken from DereChOS, VOL. V, supra note 1 at 1093-1099. Semanario Judicial de la Federación, Quinta época, t. xliii, vol. 11, p. 3520).

${ }^{105}$ See supra note 14.

${ }^{106}$ Randal C. Archibold, A Proposal to Address Rights Abuse in Mexico, N.Y, Times, Oct. 192010
} 
Article 33. Foreign persons are those who do not possess the qualities determined by article 30 of this Constitution and they shall enjoy the human rights and guarantees recognized by this Constitution.

The Executive of the Union, pursuant to a previous hearing, may expel foreign persons from the national territory based on the law which shall regulate the administrative procedure, as well as the place and time of detention. ${ }^{107}$

Considering the overall progress Mexico has made over the last four decades -especially in the areas of political and economic development, education, modernization of its legal system and foreign affairs- it is somewhat disappointing that this country took so long to finally embrace the modern concept of human rights until 2011.

Accordingly, it may be difficult to explain that almost a century had to pass since the original enactment of this article in 1917 to finally see the revision of the antiquarian and arbitrary text of Article 33 of the Constitution. The most serious challenge Mexico confronts today is the guarantee that the new text of this articleand especially the respect for human rights throughout Mexico-is to become a reality and it is not a mere rhetorical statement.

\section{A BRIEF COMMENT ON MEXICAN IMMIGRATION LAW AND PROCEDURE}

Undoubtedly, the United States possesses today one of the oldest, most detailed and highly technical immigration law system and procedure, ${ }^{108}$ that requires for its operation thousands of different technical forms especially created by the Immigration and Naturalization Service (INS) and a well-structured and specialized immigration court system.

From a historical viewpoint, the U.S. immigration system dates back to the period of 1776 to 1875 , characterized by the "Open Door Policy" then based on the notion of Unimpeded Immigration, followed by the imposition of the first immigration restrictions (1875-1917), the First Quota Systems and a number of immigration acts leading to the current Immigration Act of 1990 (as amended). ${ }^{109}$ In addition, the U.S. immigration system depends upon a highly specialized number of immigration courts and technical procedures that require an incredibly large number of technical decisions, immigration judges and immigration law attorneys.

\footnotetext{
${ }^{107}$ Decree of June 10, 2011, pp. 1 and 4, respectively (Emphasis added).

${ }^{108}$ See Richard A. Boswell. EsSENTIALS OF ImMigration LAW. American Immigration Lawyers Association (2006). The Administration and development of Immigration Law and Immigrants' Rights Under the Constitution. Washington, D.C. (2006), pp. 1-22; Ira J. Kurzban. Brief History of Immigration Laws. ImMigration LaW SOURCEBOoK (2004), pp. 1-20; David Weissbrodt and Laura Danielson. History of U.S. Immigration Law and Policy. Immigration Law and Procedure. West Nutshell Series (2010), pp. 1-61.

${ }^{109}$ See Richard A. Boswell, ESSENTIALS OF IMMIGRATION LAW 4-16 (American Immigration Lawyers Association, 2006); See also Ira J. Kurzban, IMMIGRATION LAW SOURCEBOOK 1-9 (AMERICAN IMMIGRATION LAW FOUNDATION, 1990).
} 
In contrast to the United States, Mexico does not have a structured immigration law system and immigration courts simply have never been established in that country. ${ }^{110}$ In general, unlike the United States that has opened its doors to welcoming foreign immigrants dating back to the foundation of this country, Mexico has strongly relied on its own nationals to populate the country. Foreign immigration to that country has been quite limited, sporadic and exceptional.

In Mexico, the regulation of immigration is vested upon the federal powers ${ }^{111}$ (probably influenced by the U.S. Constitution ${ }^{12}$ ) pursuant to Article 73, para. XVI of the Political Constitution that reads:

Article 73. Congress has the power:

XVI. To enact laws on nationality, legal condition of foreigners, citizenship, naturalization, colonization, emigration and immigration and the general health in the Republic.

The President, through the Secretariat of the Interior (Secretaría de Gobernación), is empowered to formulate and conduct a population policy. ${ }^{113}$

In a more detailed manner, Article 27 of the Organic Act of the Federal Public Administration (Ley Orgánica de la Administración Pública Federal (Diario Oficial of January 2, 2013, as amended) prescribes that:

Gobernación is to formulate and direct the migratory policy, oversee the borders of the country and the points of entry to same by land, sea and air, guaranteeing the freedom of transit under the law, in coordination with the other competent authorities (Para. xxxiii); be in charge of the application of article 33 of the Constitution (Para. xxxiv); and to formulate and conduct the population policy, save for colonization, human settlements and tourism, as well as to handle the national service of personal identification, under the terms of the applicable laws. ${ }^{114}$

Basically, the norms that regulate immigration matters are found in the Immigration Act (and its regulations), the General Population Act (Ley General de Población), and its regulations; the Foreign Investment

\footnotetext{
${ }^{110}$ See Constitucion Politica de los Estados Unidos Mexicanos [C.P.], Article 33, Diario Oficial de la Federacion [DO], available at http://www.dof.gob.mx/constitucion/marzo_2014_constitucion.pdf; See generally Chris Hawley, Activists blast Mexico's immigration law, USA Today, (Jan. 16, 2015), http://usatoday30.usatoday.com/news/world/2010-05-25-mexicomigrants_N.htm (article discussion Mexico's discretionary immigration system).

${ }^{111}$ DiCCIONARIO JURÍDICO. Instituto de Investigaciones Jurídicas de la UNAM, México, D.F. (2004) at 550.

${ }^{112}$ See Article 1, Sections 8 and 9 regarding the powers of Congress to establish a uniform rule of naturalization and the migration and importation of persons, respectively.

${ }^{113}$ Text taken from AGENDA DE LA ADMINISTRACION PUBLICA FEDERAL 2013. Published by Ediciones Fiscales ISEF, $26^{\text {th }}$ edition, México, D.F., January 2013 at 27.

${ }^{114}$ Id.
} 
Act (Ley de Inversiones Extranjeras); the Federal Tourism Act (Ley Federal de Turismo) and in the General Health Act (Ley General de Salud). ${ }^{115}$

The Immigration Act (Ley de Migración ${ }^{116}$ ) regulates the entry and exit of Mexican nationals and foreigners to the Mexican territory as well as the transit and stay of foreigners in the country "in a framework of respect, protection and safeguard of their human rights, their contribution to the national development and the preservation of the sovereignty and national security." (Article 1). ${ }^{117}$

This federal statute is based on a number of fundamental principles, such as: 1) the full respect of the human rights of migrants, whether national or foreigners; 2) hospitality and international solidarity to those who need a new place of residence, temporal or permanent, due to the extreme conditions in their country of origin that threaten their life, according to the Mexican tradition, the applicable treaties and international law; 3) equity between nationals and foreigners, as indicated by the Constitution especially regarding the full compliance of the individual guarantees, both for nationals and foreigners; 4) recognition of the acquired rights of immigrants, and those foreigners whose familial, labor or business in Mexico have generated a series of rights and engagements giving their daily presence in the country, even though they may have incurred in an irregular migratory situation due to administrative matters and provided said foreigner has complied with the applicable laws; and 5) family unity and the superior interest of a girl, boy or teenager, as a priority criterion for their internment and the stay of foreigners in Mexico for a temporary or permanent residency, jointly with the labor needs and humanitarian causes, whereas family unity is a substantive element for the conformation of a healthy and productive social tissue of the communities of foreigners in the country (Art. 2). ${ }^{118}$

Article 6 of this federal statute prescribes that the Mexican state guarantees the exercise and rights and freedoms of the foreigners recognized in the Constitution, in the treaties and international agreements of which Mexico is a party and in the applicable legal provisions, independently of their migratory situation. ${ }^{119}$ This statute also provides that in any case, and independently of their migratory situation, migrants have the right to the

\footnotetext{
${ }^{115}$ See Ley de Migración, Diario Oficial de la Federación [DO], 6 de Julio de 2013; Ley General de Población, Diario Oficial de la Federación [DO], 7 de Enero de 1974, available at http://www.diputados.gob.mx/LeyesBiblio/pdf/140.pdf; Ley de Inversion Extranjera, Diario Oficial de la Federación [DO], 27 de Diciembre de 1993, available at http://www.sre.gob.mx/images/stories/marconormativodoc/leyes/leyinver.pdf; Ley Federal del Turismo, Diario Oficial de la Federacion, [DO], Diario Oficial de la Federación, 17 de Junio de 2009, available at http://secturbcs.gob.mx/wpcontent/uploads/2014/07/LEY_GENERAL_DE_TURISMO.pdf; Ley General de Salud, Diario Oficial de la Federacion [DO], 7 de febrero de 1984, available at http://www.diputados.gob.mx/LeyesBiblio/pdf/142_191214.pdf

${ }^{116}$ See Ley de Migración, published in the Diario Oficial de la Federación (DOF) of July 6, 2013, as amended by DOF of July 6 , 2013 and the indispensable corresponding regulations, very lengthy and technical (Reglamento de la Ley de Migración) published in the DOF of September 28, 2012 (as amended), to be applied by Segob, the National Institute of Migration (Instituto Nacional de Migración (INAMI) and the Secretariat of Foreign Relations (SRE).

${ }^{117}$ Ley de Migración, as amended, Articulo 1, Diario Oficial de la Federación [DO], Julio 6 de 2013.

${ }^{118}$ Id. at Articulo 2.

${ }^{119}$ Id. at Articulo 6. 114 Id. at Articulo 11.
} 
rendering of justice, respecting at all time the right to due process (el derecho al debido proceso), as well as the right to file complaints regarding human rights, in accordance with the provisions found in the Constitution and in other applicable laws (Article 11). ${ }^{120}$

Mexico's Immigration Act and its technical and detailed Regulations appear to be strongly influenced by the U.S. Immigration Act.

\section{TWO LEGISLATIVE BILLS OF THE REGLEMENTARY ACT OF ARTICLE 33 OF THE CONSTITUTION}

Pursuant to the Fifth Transitory Article of the "Human Rights" decree of June 10, 2011, Congress was instructed to enact a "Reglementary Act of Article 33 of the Constitution (Ley Reglamentaria del Artículo 33 de la Constitución) regarding the expulsion of foreigners." ${ }^{121}$ Under Mexican law, a "Reglementary Act" is an specially formulated statute that details specific aspects of a given legal area. On this specific matter, two different legislative bills (Iniciativas de ley) were formulated:

1. The Senate of the Republic, during the session of August 14, 2013, several Senators of the LXII Legislature submitted to the consideration of this body a "Legislative Bill with a Draft Decree to enact a Reglementary Act of Article 33 of the Constitution." 122 This bill was sent to the Commissions of Human Rights and Legislative Studies for its study and technical opinion. ${ }^{123}$

2. During the Senate's session of October 22, 2013, President Peña Nieto, through the Secretariat of the Interior (Secretaría de Gobernación), submitted a legislative bill with a "Draft Decree to enact the Reglementary Act of Article 33 of the Constitution." On October 24, the Senate's Chair sent this bill to the United Commissions of Gobernación, ${ }^{124}$ Human Rights, Justice and Legislative Studies. ${ }^{125}$

\footnotetext{
${ }^{120}$ Pursuant to the Fifth Transitory Article, said "Reglementary Act" was to be enacted "in a maximum period of one year reckoned from the entering into force of this decree" (i.e., June 11,2012). Until said Act is enacted, "Article 33 shall continue to be applied in the terms of the current text." (As of the writing of this article, i.e,, September 2014, said Reglementary Act had not been published in the Diario Oficial).

${ }^{122}$ Pursuant to Art. 71 of the Constitution, the right to initiate laws or decrees is vested: I) In the President of the Republic; II. Deputies and Senators of the Congress of the Union; III. The States' Legislatures; and IV. The citizens under certain requirements. ${ }^{123}$ See Iniciativa del día [Daily initiative from Mexican Senate], 14 de Agosto de 2013, Senado de la Republica, available at http:/www.senado.gob.mx/?ver=sp\&mn=2\&id=42998.

${ }^{124}$ Pursuant to the Organic Act of Mexico's Federal Public Administration (Ley Orgánica de la Administración Pública Federal), Secretaría de Gobernación (Secretariat of the Interior or Segob, as it is commonly known) appears to be the most important and politically powerful Secretariat of State (out of a total of 16 Secretariats). Jointly with the President of the Republic, Segob inter alia "coordinates the other Secretaries of State regarding political matters, formulates and submits to Congress any legislative bills generated by the President; presides the National Council of National Security, assists federal, state, and municipal authorities, including the Judicial Power and the Attorney General," etc. It controls political activities, immigration and population policies, casinos and gambling, and elections at the national level as well as intelligence operations. For a long and detailed list of functions, see Article 27 of the Federal Public Administration Act.
} 


\section{Senate's Legislative Bill with a Draft Decree to Enact a Reglementary Act of Article 33 of the Constitution (Ley Reglamentaria del Artículo 33 de la Constitución), dated August 14,} $2013 . .^{126}$

The Senate's Commissions of Human Rights and Legislative Studies recognized that the amendment made by President Felipe Calderon Hinojosa to Article 33 of the Constitution by decree of June 10, 201 1, is one of the central components of the so called "Human Rights Reform." ${ }^{127}$ The Senatorial Commissions clearly underlined that the new text of this article recognizes:

1. that foreign persons enjoy the human rights and individual guarantees granted by the Constitution;

2. the right of a foreign person to have a hearing (Derecho de audiencia guaranteed by the revised text of Article 33 of the Constitution) prior to his/her expulsion;

3. the need to formulate a clear, fair and modern administrative procedure regulating the expulsion of foreign persons;

4. Congress was instructed to enact a Reglementary Act (Ley Reglamentaria) on this matter to regulate each and every phase of the corresponding administrative procedure;

5. in accordance with Article 33 of the Constitution, all foreign persons subject to the new administrative procedure of expulsion enjoy, inter alia: a) their legitimate right to be presumed innocent; ${ }^{128}$ (b) the right to have an adequate legal defense; ${ }^{129}$ (c) the right to manifest what the law recognizes; (d) the right to offer evidence during the new administrative procedure; ${ }^{130}$ (e) the right that said administrative procedure is to be conducted within the spirit of respect, protection and safeguard of human rights, ${ }^{131}$ as well as the preservation of the sovereignty and the national security. ${ }^{132}$

Given the transnational repercussions the new administrative procedure for the expulsion of foreigners is expected to produce at the international level, the Senatorial Commissions in charge of formulating said

${ }^{125}$ The discussion of President Peña Nieto's Legislative Bill appears infra, in Section V at page 27.

${ }^{126}$ Iniciativa del día 14 de Agosto de 2013. Fuente: http:/ www.senado.gob.mx/?ver=sp\&mn=2\&id=42998.

127 See Decreto por el que se modifica la denominación del Capítulo I del Título Primero y reforma diversos artículos de la Constitución Política de los Estados Unidos Mexicanos [Decree to modify and reform diverse articles of the Mexican Constitution], Diario Oficial [DO], 10 de Junio de 2014 available at http://dof.gob.mx/nota_detalle.php?codigo=5194486\&fecha=10/06/2011

${ }^{128}$ This right, guaranteed by Article 20, para. B-1, of the Constitution is transplanted from criminal law, mutatis mutandis, to the immigration area.

${ }^{129}$ This right transplanted Article 20, Section C-1 of the Constitution from the criminal law area to the immigration area.

${ }^{130}$ Taken also from Article 20, Section B, para. IV, and then transplanted, mutatis mutandis, to the immigration law area.

${ }^{131}$ Derived from Article 1 of the Constitution.

${ }^{132}$ Senate's Legislative Bill of 14 August 2013. Segundo Receso, Primer Año de Ejercicio, LXII Legislatura, Miércoles 14 de Agosto de 2013, Gaceta:29. Eighteen Senators formulated and supported this bill that may be found at: http: / /www.senado.gob.mx/?ver=sp\&mn=2\&sm=2\&id=42998 
procedure took into consideration not only the domestic and constitutional angles embedded in it but also, in a very special manner, human rights principles, ${ }^{133}$ legal principles recognized on this matter by certain countries (such as, inter alia, the United States, ${ }^{134}$ the United Kingdom ${ }^{135}$, Germany ${ }^{136}$ and France ${ }^{137}$, in a comparative law exercise) legal and human rights principles found in specific international conventions ${ }^{138}$ as well as decisions and opinions rendered by international tribunals.

In many respects, the new administrative procedure of expulsion parallels mutatis mutandis the procedure followed by Mexico in criminal proceedings (clearly detailed in Article 20 of the Constitution ${ }^{139}$ ), subject to the pertinent adjustments to this new immigration law area.

In response to this mandate, the Senate's Commissions of Human Rights, Gobernación, Justice, and Legislative Studies discussed said Reglementary Act (Ley Reglamentaria) whose object is " $[\mathrm{T}] \mathrm{o}$ regulate the procedure through which the federal Executive shall exercise the power to expel from the national territory foreign persons who, legally found within the national territory, incur in some of the situations contemplated by the Constitution." ${ }^{140}$ In its Communique, the Senate indicated that:

The expulsion procedure established by the new Reglementary Act "may not exceed 30 natural days and when this term is over and the Executive did not issue an opinion, the proceedings are to be concluded, and the detention and cautionary measures are to be lifted.

\footnotetext{
${ }^{133}$ See Article 6 of the Draft Decree proposed by the Senate that includes "guiding human rights principles" such as legal equality between men and women; respect for human dignity, family unity; presumption of innocence; proper interpretation and interpretation favoring the person (Principio pro-persona), etc.

${ }^{134} \mathrm{As}$ a country of immigrants, the U.S. Immigration law is universally recognized as a source of sound immigration law principles; immigration procedures and institutions; immigration terminology; the creation of immigration courts; categories of immigrants and non-immigrants, Immigration Forms, etc. but, especially, Chapter IV-Inspection, Apprehension, Examination, Exclusion, and Removal of the Immigration and Nationality Act. See IMMIGRATION AND NATIONALITY LAWS OF THE UNITED STATES (Selected Statutes, Regulations and Forms) by T. Alexander Aleinikoff, David Martin and Hiroshi Motomura. Thomson West (2007), pp.1343. See also ImMigRATION LAW SOURCEBOOK. Ira J. Kurzban. American Immigration Law Foundation, $8^{\text {th }}$ Edition (2002) and Richard A. Boswell. ESSENTIALS OF IMMIGRATION LAW. American Immigration Lawyers Association (2006)

${ }^{135}$ See generally Impact in 47 Countries, European Convention on Human Rights, (Jan. 17, 2015, 3:38PM), http:/ /human-rightsconvention.org/impact-of-the-european-convention-on-human-rights/ (listing European members of the Convention); See also Council of Europe, European Convention for the Protection of Human Rights and Fundamental Freedoms, as amended by Protocols Nos. 11 and 14, 4 November 1950, ETS 5, available at http://en.wikisource.org/wiki/European_Convention_for_the_Protection_of_Human_Rights_and_Fundamental_Freedom $\mathrm{s}$

${ }^{136} \mathrm{Id}$.

${ }^{137} \mathrm{Id}$.

${ }^{138}$ Convention and Protocol relating to the Status of Refugees, Convention Against Torture and Other Cruel, Inhuman, or Degrading Treatment or Punishment, Articles 1-16; International Pact of Civil and Political Rights, American Convention on Human Rights, International Convention on the Protection of the Rights of All Migratory Workers and their Families, Convention on the Condition of Foreigners (La Habana, Cuba, February 20, 1928), etc.

${ }^{139}$ The essential components of this procedure (both substantive and adjective) were clearly inspired by the criminal procedure established in the U.S. Constitution.

${ }^{140}$ Comunicado 690: Aprueban Comisiones Reglamentar Expulsión de Extranjeros y la Restricción de Derechos. Senado de la República, Coordinación de Comunicación Social, Abril 14, 2014. The Senate’s Commissions approved to regulate the expulsion of foreigners and restrict their rights. Senate’s Communique-690 dated April 28, 2014.
} 
Gobernación may impose one or more cautionary measures (fianza or garantía económica), which may consist of a cash deposit made with a financial institution or through a bond, for the amount determined by the competent authority;

The obligation to report in person periodically before the authority; the prohibition or restriction to attend certain meetings; or to communicate with certain persons when they are related to the facts and, finally, the retention of the passport;

From the moment the foreign person is personally served with the notification of the administrative procedure said person shall be informed of his/her right to receive consular assistance, and to maintain communication with his/her consul;

The foreign person shall be detained at the time when personal notice is given of the initiation of the proceedings established by the new Act and shall remain in the migratory installations or in similar places;

The decision to expel is to be personally notified to the foreign person immediately and the administrative authority shall detain said person keeping him/her under custody until he/she is expelled from the country, which is to take place, at the latest, 36 hours after his/her detention; ${ }^{141}$

When an expulsion applies to a foreign person subject to a criminal procedure or that has been sentenced for a criminal offense, the expulsion shall take place once the procedure is concluded or the sentenced imposed has been served. ${ }^{142}$

With the approval of this technical opinion (Dictámen del Senado), the reform published in 2011 granting a series of rights for the benefit of Mexican citizens and foreigners is considered to have been complied with and the law of Mexico is now in symmetry with the conventions, international treaties and principles of public international law on this matter that have been ratified by Mexico. ${ }^{143}$

\section{Content of the Senate's Legislative Bill}

In the introductory remarks (Exposición de Motivos) this bill indicates that, in formulating its bill, the Senate took into consideration a number of international instruments, in particular (a) Article 13 of the International Pact on Civil and Political Rights, and (b) Articles 8, 32 and 33 of the American Convention on

\footnotetext{
${ }^{141}$ Given the speed of the proceedings and the quick resolution of the case, it would seem that this procedure may be considered as a "Super express administrative procedure of exclusion."

${ }_{142}$ See Senate's Legislative Bill of 14 August 2013, Senado de la Republica, available at http://www.senado.gob.mx/?ver=sp\&mn=2\&sm=2\&id=42998

${ }^{143}$ Senate's Communique-690, Ibid.
} 
Human Rights, as well as a number of opinions and "Jurisprudencias" rendered by Mexico's Supreme Court pertaining to Articles $1,13,14,16$ of the Constitution. ${ }^{144}$

From a substantive viewpoint, the Senate's bill is composed of these six chapters: I) General Provisions (Arts. 1-8); II) Administrative Procedure for the Expulsion of Foreign Persons (Arts. 9-26); III) Powers and Obligations of the Competent Authority (Arts. 27-29); IV) Guarantees of Foreign Persons subject to the Administrative Procedure of Expulsion (Arts. 30-40); V. Places and Conditions of Detention of Foreign Persons on Expulsion Proceedings (Art. 41); and VI. Foreign Persons Involved in the Political Matters of the Country (Arts. 42). ${ }^{145}$

\section{Chapter I: General Provisions}

This last chapter underlined out that the object of the Reglementary Act (Ley Reglamentaria) is to regulate and establish the due process for the exercise of the fundamental right to a hearing consecrated now by the recently amended Article 33 of the Constitution. So "any foreign person subject to an exclusionary administrative procedure may exercise their legitimate right to their defense in an administrative framework of respect, protection and safeguard of their human rights, as well as the preservation of the sovereignty and national security" (Art.1).

The indispensable elements and requirements needed to initiate the administrative procedure of exclusion include the following (Art.3):

The corresponding order is to be issued by the President of the Republic; It should articulate the reasons that justify the expulsion of a foreign person; Be in strict compliance with the public interest and the national security; Be in writing with the autograph signature of the Executive of the Union; Be applicable to the specific case in question and be based on the applicable law;

Be subject to the procedure established by the Reglementary Act; Include the complete name of the foreign person; and Include place and date of the expulsion procedure.

Article 4 explicitly indicates that in Mexico -contrary to the arbitrary language in the original version of Article 33 of the Constitution - "all foreign persons shall enjoy the human rights recognized in the Constitution and in the international treaties to which the Mexican state is a party, as well as the guarantees (Garantías individuales) for their protection whose exercise can neither be restricted nor suspended, save in the cases and under the conditions this Constitution and this [Reglementary] Act establish.

\footnotetext{
144 See Senate's Legislative Bill of 14 August 2013, Senado de la Republica, available at http: / /www.senado.gob.mx/?ver=sp\&mn=2\&sm=2\&id=42998.

145 See Senate's Legislative Bill of 14 August 2013, Senado de la Republica, available at http: / /www.senado.gob.mx/?ver=sp\&mn=2\&sm=2\&id=42998
} 
Article 5 refers to the novel notion called "Control Difuso de Convencionalidad" (sic). This control is a test that the public authority has to pass "to verify and guarantee that its actions are in full compliance with the obligations that, as an authority, it has to comply with in full symmetry with the applicable treaties that legally bind Mexico." Article 6 enlists fifteen principles the competent authority must comply with in the human rights area. Some of these principles are: universality, interdependence, indivisibility, progressivity, legality, no discrimination, superior interest of children, family unity, equality between men and women, presumption of innocence, due diligence, etc. Article 7 reiterates that the exclusionary administrative procedure is to comply with the essential formalities of due process (a notion transplanted from the U.S. legal system), treaties binding Mexico as well as "norms and sources of customary international law." (sic).146

Article 8 provides the legal definition of the sixteen principles and legal terms, including universality, interdependence, indivisibility, progressivity, legality, superior interest of children, no discrimination, equality between women and men, respect for human dignity, family unity, due diligence, administrative procedure, etc. This procedure is defined as the phases and guarantees that should be followed and respected to comply with the right to a hearing that a foreign person is to have when the Executive of the Union (i.e., the President) has notified said foreigner of his/her expulsion of the country, in accordance with what has been established by the Constitution, the international treaties to which Mexico is a party and the applicable laws.

\section{Chapter II: Administrative Procedure for the Expulsion of Foreign Persons}

Article 9 prescribes that the administrative procedure of exclusion can only take place when it is fully proven that the foreign person is a threat to the public interest or the national security, as prescribed by the National Security Act (Ley de Seguridad Nacional). Article 10 reiterates that said administrative procedure is to be regulated by the Reglementary Act of Article 33 and the applicable administrative provisions. During this procedure, the human rights of foreign persons are to be fully respected.

Article 11 mandates that the notification of the foreigner who is to be subject to an exclusionary administrative procedure has to be done personally ("De manera personalísima") and immediately, notifying him/her of the place, date, time and object of said procedure, as well as the consequences if the foreigner does not attend said procedure. Said notification is to inform about the reasons for the procedure, the applicable facts and the corresponding evidence, so the foreigner is to be able to prepare his/her defense. Article 12 prescribes that the authority is to inform the foreigner the appeals (Recursos) and the corresponding terms to be filed against the

\footnotetext{
${ }^{146}$ Over the last two or three decades, Mexico has fully incorporated into its legal system a number of legal principles taken directly from the U.S. legal system such as due process, presumption of innocence, no discrimination, etc. See Annex One at the end of this article.
} 
resolution of the Executive. The competent authority is to inform the authorities of the country of nationality of the foreigner so these may be able to provide legal and consular assistance.

Pursuant to Article 13, starting from the initial notification served to the foreigner, the administrative procedure of exclusion is to have a maximum length of five working days. Article 14 prescribes that to impede that the foreigner may abscond from the procedure, the competent authority may impose the following cautionary measures: i) Retention of passport; ii) Fine; iii) Police monitoring; iv) Prohibition to leave certain territorial area; and v) Detention. Foreign persons to be subjected to an exclusionary procedure may use the three days following their notification to present their defenses and to offer evidence (Art. 15). The Executive Power in these exclusionary proceedings may be represented by the Head of the Legal Office of the Federal Executive (Consejería Jurídica del Ejecutivo Federal de la República) (Art. 16).

The exclusionary procedure is to end by (1) its proper and final resolution; (2) by the withdrawing of the charges by the Executive; (3) to renounce the right serving as the basis of the request; (4) the expiration of the action (Declaración de caducidad); and (5) the material impossibility to continue with the procedure (Art. 17). The competent authority is to produce the corresponding resolution in a period not longer than 24 hours, reckoned from the date of the hearing (Art. 18); the resolution of the competent authority shall be definite to be challenge only through an Amparo proceeding, pursuant to Article 107 of the Amparo Act ${ }^{147}$ (Art. 19). When a foreign person is to be detained for reasons of national security, said detention may not exceed five working days (Art. 20); When a foreign person is detained as a result of an exclusionary proceeding, said person shall be sent to an installation especially created for that purpose, under the custody of a competent authority, guaranteeing his/her physical integrity and human dignity (Art. 21); Detained foreign person who are subject to an exclusionary proceeding cannot be sent to penitentiary centers, migratory stations or other type of installation destined to deprive persons from their freedom because of the commission of a criminal offense (Art. 22).

Once the five days that an exclusionary proceeding have lapsed, and in those cases where the Executive of the Union decides to expel a foreign person, the competent authority is then to expel the foreign person in question to the country of his/her origin, through the appropriate avenues, in accordance with what has been established by the applicable legislation as well as in the international treaties (Art. 23). The expulsion implies the prohibition to re-enter the Mexican territory. The duration of said prohibition shall be determined considering the circumstances in each case (Art. 24).

Article 25. The expulsion of foreign persons from Mexico's national territory shall not take place in any of the following cases:

\footnotetext{
${ }^{147}$ The Amparo Act (Reglementary of Articles 103 and 107 of the Constitution) provides a federal lawsuit to resolve controversies resulting from "general norms, acts or omissions of any authority that violate the human rights or the individual guarantees granted by the Constitution and by the international treaties to which the Mexican State is a party" (Art. 1).
} 
1. When it breaches the principle of Non-refoulement, when the foreign person requests asylum, refuge or complementary protection in accordance with the applicable law and in the international treaties;

2. When the foreign person's health is at risk;

3. When the foreign person is pregnant and the administrative procedure of expulsion may represent a risk for the gestation of the baby or for her health;

4. When the foreign person has no nationality;

5. When there is no valid information regarding his/her identity and/or nationality or there is difficulty in obtaining identity and traveling documents;

6. When the consulates or consular sections of the country of origin or residence require longer time for issuing said documents;

7. When there is an impediment for his/her transit through third countries or an obstacle to establish the itinerary of the trip to the final destination;

8. When there is illness or physical or mental incapacity recognized by a medical doctor that impedes any traveling;

9. When the foreign person is a victim of prostitution and/or gender violence, or is a witness of crimes committed in Mexico's national territory, whose proceedings are still undergoing;

10. When they are first degree ascendants of persons who are minors with a Mexican nationality and who live in Mexico's national territory;

11. When they are first degree ascendants of persons who are minors that depend directly from them and they are in Mexico's national territory;

12. When they are under 18 years of age;

13. When the foreign person is subject to a criminal proceeding or has been sentenced for a serious crime (Delito grave) according to national laws on criminal matters or the provisions found in treaties and international agreements.

14. When there is a possibility that the foreign person may be sued in the country of his/her origin or in some of the countries through which he/she has to transit towards his/her final destination and is to be sentenced to death;

15. When they are journalists or human rights defenders according to what is established by the applicable legislation;

16. When there is pressure or a request from a foreign government in which case the extradition procedure is to be followed; 
17. When a minor who is within Mexico's national territory may be affected by the exclusionary proceeding of a foreign person, the competent authority shall take into account the principle of the superior interest of the child (Principio de interés superior de la infancia) and shall proceed in accordance with what is provided by Articles 5 and 6 of this Act.

Summary or collective expulsions of foreign persons are prohibited as well as the systematic expulsion of foreign persons of the same nationality (Art.26).

\section{Chapter III: Powers and Obligations of the Competent Authority}

The application of the Reglementary Act of Article 33 of the Constitution corresponds to Secretaría de Gobernación (Secretariat of the Interior) that may be assisted by other dependencies and entities of the Federal Public Administration whose attributions may be related with migratory matters and with the compliance of the principles and objectives supporting this Act (Art. 27). Independently of being subjected to an expulsion administrative procedure, the competent authority shall guarantee the right of foreign persons to submit human rights complaints pursuant to the provisions found in the Constitution, international treaties and other applicable laws (Art.28)

Families of foreign persons undergoing an expulsion administrative procedure, while in Mexico's national territory, shall have right to receive information regarding: (i) their rights and options pursuant to the current legislation; (ii) the requirements established by the applicable legislation for their permanency or exit of the national territory; (iii) The existence of the possibility of requesting the condition of refugee, the granting of complementary protection or the concession of political asylum and the determination of having no country (apátrida), as well as the respective procedures for obtaining said conditions, in accordance with has been established in the legislation and applicable treaties. The competent authority shall adopt the appropriate measures to inform the families said information, according to the applicable regulations (Art. 29).

\section{Chapter IV: Guarantees of the Foreign Persons subject to an Administrative Procedure of Expulsion.}

Foreign persons subject to the administrative procedure of expulsion shall have the right that the competent authority is to inform them of the legislation and international treaties signed by the Mexican State relating to the foreign persons legal regime, and any other that may benefit them (Art. 31). When a foreign person does not speak or understand the Spanish language, a translator and an interpreter shall be appointed to facilitate the communication. When the foreign person is deaf but knows how to write and read, the interrogation shall be 
done in writing or through an interpreter. Otherwise, an interpreter who can understand it shall be designated (Art. 32). Foreign persons subject to an administrative procedure by the Executive to expel them from the national territory, shall have the right to: a) Leave the national territory through the places designated for the international transit of persons; b) Identify themselves through a passport or identity or traveling document, valid and current; c) To be sent back to their country of origin or to the country from which they are nationals (Art. 33).

During the expulsion administrative procedure the foreign persons shall have the right that the competent authority guarantee the rights established by the Constitution, by this Act and by the international treaties of which Mexico is a party (Art. 34). Every foreign person has the right to be legally assisted or represented by an attorney designated during said procedure by the foreign person. Otherwise, the State is obligated to provide him/her an attorney (Abogado de oficio) (Art. 35). The competent authority may enter into required collaborative agreements (Convenios de colaboración) and shall establish facilities so civil organizations may provide legal advisory services and legal representation to foreign persons subject to an expulsion administrative procedure (Art. 36). Foreign persons subject to said administrative procedure or their legal representatives may request certified copies of the documents submitted to said procedure and of the resulting resolutions which may be delivered to them no more than twelve hours after they were requested (Art. 37). Foreign persons subject to an administrative procedure of expulsion shall have the right that a representative of the National Commission of Human Rights be present at the hearings (audiencias) before the competent authority, verify the respect to their human rights and supervise the conditions of their detention, independently of the work conducted by his/her legal representative or of the person of his/her confidence that may be designated for that purpose (Art. 38).

Independently that foreign persons subject to an administrative procedure of exclusion exercise their right that a representative of the National Commission of Human Rights be present at the hearings before the competent authorities, said Commission shall include in its annual report before Congress (Congreso de la Unión) a report on the compliance of this Act and on the respect to the human rights of foreign persons that the head of the Federal Executive Power, in the exercise of his constitutional power, has decided to expel (Art. 39). The expenses regarding the sending back of the foreign person to his/her country of origin or the country where he/she is a national of, shall be charged to the budget of the competent authority. In no case the foreign person is to be obligated to pay the cost of his/her expulsion (Art. 40).

Chapter V: Place and Conditions of Detention of Foreign Persons to be Expelled from Mexico

During the period of detention to expel a foreign person for reasons of national security, those foreign persons placed under the custody of the competent authority, shall have the right to: 
1. Medical, psychological and spiritual assistance;

2. Sufficient food of the appropriate quality (sic);

3. Persons with special needs and persons of the third age (i.e., Senior citizens) shall receive an adequate diet, so their health shall not be adversely affected;

4. When a medical doctor has so prescribed, the foreign person may have a special diet. A similar treatment shall be given to persons based on religious considerations and at their request; and

5. To remain in an adequate place that guarantees his/her security, human dignity and physical integrity.

Chapter VI: Foreign Persons involved in the Political Matters of the Country

Foreign persons who become involved in the political matters of the country may be expelled from the national territory in accordance with what has been established by this Act, provided the competent authority considers that their permanency in the country poses a risk to the public interest or the national security, independently of those sanctions that correspond for the commission of anti-legal behaviors considered as electoral crimes (Delitos electorales) (Art. 42).

\section{PRESIDENT PEÑA NIETO SUBMITS TO CONGRESS A "DRAFT DECREE OF THE REGLEMENTARY ACT OF ARTICLE 33 OF THE CONSTITUTION.” 148}

In his letter to Congress, ${ }^{149}$ President Peña Nieto alluded to the importance of the Human Rights reform of 2011 that he considered as a key foundation for the Mexican state. He asserted that today all persons in Mexico enjoy the human rights recognized by the constitution and by those international treaties and conventions to which Mexico is a party, concluding that said rights are to be interpreted in accordance with the principles of universality, interdependence, indivisibility and progressivity.

\footnotetext{
${ }^{148}$ Article 71, para. 1 of the Constitution grants power to the President of Mexico "to initiate laws and decrees," jointly with the Representatives (Diputados) and Senators to the Congress of the Union, the States' Legislatures and Mexican citizens (under certain conditions).

${ }^{149}$ Letter to the President of the Chamber of Senators of the Hon. Congress of the Union dated October 21, 2013 (Oficio al Presidente de la Mesa Directiva de la Cámara de Senadores del H. Congreso de la Unión). As of the writing of this article (September 2014), the Reglamentary Act of article 33 of the Constitution had not been published neither in the Diario Oficial de la Federación (similar to the Federal Gazette) nor in the Gaceta Parlamentaria of the Mexican Congress of the Union, in violation of Transitory Article V that mandated: "The Congress of the Union shall enact a Reglementary Act of Article 33 of the Constitution (Ley Reglamentaria del artículo 33 de la Constitución) in matters concerning the expulsion of foreigners within a maximum term of one year reckoned from the beginning of the entering into force of this decree." Pursuant to Transitory Article I, this decree entered into force on June 11,2011, on the day following its publication in the Diario Oficial. (Surprisingly, the text of this initiative -in the official paper of Presidencia de la República, with the official seal of Mexico and the autograph signature of President Enrique Peña Nieto) was found and downloaded from Google!).
} 
However, he pointed out that this constitutional reform is not to produce the desired consequences unless new proposals and changes are to take place through the enactment of the corresponding secondary legislation. Within this context, the proposed reforms to the constitution are to be in symmetry with international law. Today, Article 33 of the constitution prescribes that foreign persons shall enjoy the human rights and guarantees recognized by the constitution, clearly pointing out that the head of the Federal Executive may expel foreign persons from the national territory provided the principles of legality and the right to be heard in court are fully respected.

Therefore, President Peña Nieto indicated that it is indispensable to enact a specific statute establishing the corresponding procedure. Moreover, in order to comply with the mandate in Transitory Article Five of the Decree that changed the name of Chapter I, Title I of the constitution (published in the Diario Oficial on June 10, 2011), President Peña Nieto already submitted to Congress a draft legislative bill of his proposed "Reglementary Act of Article 33 of the Political Constitution of the United Mexican States" (Ley Reglamentaria del Artículo 33 de la Constitución Política de los Estados Unidos Mexicanos). ${ }^{150}$

The Executive suggested to Congress that, since this body that is to harmonize the constitution with the fundamental principles of international law -reason that led to the substantial reform of Article 33 predicating that foreigners enjoy the human rights and the guarantees recognized by the constitution- and, above all, underline that the Federal Executive can only expel foreign persons from the national territory provided that the principle of legality and the right to a hearing are fully respected. Therefore, in his letter to Congress the President made it clear that it was indispensable to enact a statute establishing the corresponding procedure.

The Federal Executive is familiar with the principle that all the organs of the State should comply with the orders issued by the Permanent Constitutional Power (Poder Constituyente Permanente). Consequently, with the goal of collaborating with the Federal Legislative Power, the Executive proceeded to comply with the tenor of the Fifth Transitory Article of the Decree that changed the name of Chapter I of the First Title and reformed several articles of the Political Constitution of the United Mexican States (published in the Official Gazette of June 10, 2011), prescribing that: "The Congress of the Union shall enact a Reglementary Act of article 33 of the constitution regarding the expulsion of foreigners in a maximum term of one year reckoned from the entering into force of this decree..." Therefore, the President decided to submit to the consideration of the Congress of the Union a draft of a legislative bill issuing the "Reglementary Act of Article 33 of the Political Constitution of the United Mexican States."

\footnotetext{
${ }^{150}$ President Peña Nieto's letter, dated October 21, 2013, was addressed to the President of the Senate (Cámara de Senadores) of the Hon. Congress of the Union.
} 


\section{Reform to Article 33 of the Political Constitution of the United Mexican States}

Regarding the revised language of article 33 of the Constitution, ${ }^{151}$ the reform of June 201 ladded two fundamental topics placed within the current constitutionalism, namely:

1. The right to a hearing (Derecho de audiencia) in favor of any foreign person who is to be expelled from Mexico; and;

2. The legal regulation of the administrative procedure of expulsion, as well as the place and time of the detention.

These recent additions to article 33 of the constitution imposed the obligation to the Federal Executive to respect the right to a hearing in accordance with the law that regulates the procedure, thus adjusting the constitutional text to the international norms.

It is fundamental to notice that, according to article 22.6 of the American Convention on Human Rights, the Mexican state is obligated that "the foreigner legally found within the territory (...) may only be expelled from it in compliance with a decision taken according to the law," considering that article 8 of said Convention prescribes the guarantee of a hearing (Garantía de audiencia) in any matters that decide upon his/her rights.

There is no doubt from the viewpoint of the Federal Executive the circumstances under which the original Constitutional power drafted this constitutional provision were quite different to the current situation, and that universal postulates of due process (Debido proceso) obligate to grant the guarantee of a hearing (Garantía de audiencia) in any case where there is the mere possibility that the exercise of a right by any given person may be deprived.

he considerations advanced by the Joint Commissions of Constitutional Points and of Legislative Studies of the Senate, pointed out that:

These Joint Commissions decided to accept the reform to Article 33 of the constitution; however, this reform must comply with the objective of guaranteeing the protection of the human rights recognized by said constitution to foreign persons.

The text of the second paragraph of article 33... maintains the historical power of the Federal Executive to expel foreign persons from the national territory; however, in consonance with the ample protection of the human rights and the guarantees for their protection incorporated by this constitutional amendment, it is established that the administrative procedure should respect the guarantee to a hearing (Garantía de previa audiencia), eliminating any contrary elements to this guarantee.

\footnotetext{
${ }^{151}$ The revised and current text of Article 33 of the Constitution (as amended by the Decree of June 10,2011) appears in footnote 62, supra.
} 
Therefore, the principle of the reservation of the law (Principio de reserva de ley) is to be added for the secondary legislation to be able to determine with precision the place and time that the respective detention is to last, as well as the procedural phases (etapas del procedimiento) which are to be expeditious and in a sole hearing (uninstancial).

These Joint Commissions propose also that during the transitory regime the obligation of the Congress of the Union to enact the respective Reglementary Act in a period not longer than a year, is to be established.

\section{International Context}

Article 13 of the International Pact of Civil and Political Rights (to which the Mexican State adhered to on March 23, 1981) expressly recognizes the guarantee of legality (Garantía de legalidad) and the right to a hearing (Derecho de audiencia) for the benefit of foreign persons who may be affected by an expulsion, as well as the right to submit their case before a competent authority.

This international instrument recognizes that, unless imperative reasons of national security are opposed to it, a foreigner should to articulate the reasons that assist him/her against said expulsion, and to submit his/her case to be revised before the competent authority and be represented before said authority for that purpose.

This is replicated in other treaties, such as the 1951 Geneva Convention on the Status of Refugees, whose article 32 provides that the States "shall not expel any refugee who is legally in the territory of said States, unless for national security reasons or of public order." It is also established that "the expulsion of the refugee shall take place, in that case, by virtue of a decision taken in accordance with the legal procedures in force. Unless imperative reasons of national security are opposed to it, the refugee is to be allowed to submit exculpating evidence, to make an appeal and to be represented before the competent authority or before one or several persons especially designated by the competent authority."

On the other hand, article 22 of the American Convention on Human Rights (to which the Mexican State deposited the adhesion instrument on March 24, 1981) prescribes the expulsion of foreigners legally found within the territory of one of the State parties; however, said convention is limited to complying with a decision adopted according to the law.

In identical terms, the International Convention on the Protection of the Rights of all Migratory Workers and their Relatives (ratified by the Mexican State on March 8, 1999) provides in its Article 22.2 that "the migratory workers and their relatives may only be expelled from the territory of a State Party in compliance with a decision adopted by the competent authority in accordance with the law."

The Mexican government ratified the American Convention on the Condition of Foreigners adopted at La Habana, Cuba, on February 20, 1928, but a reservation was made regarding the right of expulsion established in 
article 6 of said convention, in the sense that "Mexico shall exercise the right of expulsion in the manner established by its Constitution." Article 6 prescribes that the States may, because of order or public security, expel a foreign person domiciled, resident or simply passing through its territory, as well as the obligation of the States to receive nationals that, expelled from abroad, are going back to their territory.

The Convention on the Condition of Foreigners establishes principles that continue to be valid, such as is the case when the expelled foreigner should be received in any State Party and not necessarily in the State of his/her origin or nationality; however, given the current international context, it is required to update the scope of its content, principally article 6, which Mexico has done through the enactment of a statute respecting the human rights of foreigners, especially those rights relative to due process, in accordance with the international standards established in human rights treaties to which the Mexican State is a party. Accordingly, the proposed procedure in President Peña Nieto's legislative bill adheres to the international standards on this matter and, also allows for the update of the objectives of said Convention.

Therefore, the international standards protecting the human rights of foreign persons subject to an expulsion procedure, as well as those who have been expelled, point to the legality of the procedure and the determination of the competent authority regarding said expulsion. Clearly, its objective is to guarantee due process.

\section{Domestic Context}

States have the sovereign right to admit foreign persons in its national territory, or to reject their admission; equally, they have sovereign powers to regulate their permanency. Although it is true that in international law there are limits for the States to affect the legal condition of foreigners -as it is observed in the different international provisions already mentioned- this does not negate the sovereign power of the receiving States to expel foreigners who attempt against the national security or that in some other way affect the public order. Also, the national sovereignty includes the power of the State to establish its own migratory policy. This implies the possibility of making foreign persons to abandon their territory.

Following the criteria of the extinct European Commission of Human Rights, it is possible to affirm that the expulsion of foreign persons, as part of a policy of migratory control and regulation, is necessary to safeguard the national security, if States would so consider it.

It is important to underline that within the United Nations Organization the possibility of expulsion has also been recognized. The best example is the already cited article 13 of the International Pact of Civil and Political Rights, legally binding to 167 States including Mexico. In the same fashion, the Committee on Human Rights of the United Nations, in charge of the supervision of the enforcement of said Pact, in its General Observation No. 
15, relative to "The situation of foreigners according to the Pact" (adopted in its $27^{\text {th }}$ period of sessions in 1986) points out that "the principles of article 13 relative to the appeal of an expulsion and the right to the review of the case by the competent authority can only be omitted for imperative reasons of national security."

Currently, the international community analyzes and progressively develops aspects relative to the protection of the human rights of an expelled or to be expelled person, as limits to the right of the State to expel foreigners. This can be seen, in a particular manner, in the work of the United Nations Commission of International Law. In effect, the Commission, in its $64^{\text {th }}$ period of sessions in 2012, approved, in a first reading, the draft articles on the expulsion of foreigners which appears in the report of the Commission to the United Nations General Assembly (see document A/67/10, pp. 11 to 18).

\section{Comparative Law}

With the purpose of strengthening the current legislative proposal, comparative law has been included in the proposal made by President Peña Nieto to incorporate the best standards in the matter of protection to human rights regarding the expulsion of foreign persons. This has been done with the purpose of inhibiting and not allowing at any moment the arbitrariness of the competent authority to render an opinion regarding the expulsion of a foreign person and, at the same time, assure a complete and absolute respect to the fundamental human rights of an foreign person.

In this sense, the laws of Germany and Spain, in regulating the expulsion of foreign persons contribute elements that, at the same time that the national security is protected, the public security and public order effectively protect the human rights of the foreign persons susceptible to be expelled. This is abundantly clear when both laws point out that several factors are to be taken into account prior to the expulsion, inter alia: the proportionality, the seriousness of the damage produced by the foreigner, the duration of the residency in the country, the family relationships developed during said residency and the objective of not evading international obligations established in human rights treaties. The latter is also expressly recognized in the provisions on deportation of the United Kingdom. From another angle, it is clear that, within the European context, treaties on human rights control define the discretion of the competent authorities at the moment of deciding on the expulsion.

The legislation of Canada expressly points out which are the places of detention, as well as that of Spain, that also refers to the nature of said places to be different than penitentiary centers. In the case of Canada, these are the Offices of the Division of Immigration and in the case of Spain the Internment Centers in the Halls of Frontier Admissions (Centros de Internamiento en Salas de Admisión de Fronteras). 
President Peña Nieto's legislative bill considered that the most convenient in terms of legal security and protection of human rights is to expressly establish two aspects: first, the identification of the places of detention and, second, that in the physical space destined for the detention the human rights of foreign persons are to be fully respected.

The comparison among the laws from other countries in matters of expulsion of foreigners, not only allows to learn about the advances on this topic in general terms but it also provides a point of reference and a legal source for the formulation of this legislative bill incorporating the most advanced aspects of said laws regarding the protection of the human rights of foreign persons. This task may assist in complying with the third paragraph of article 1 of the Political Constitution of the United Mexican States in the sense that all authorities, within the ambit of their functions, are under the obligation of promoting, respecting, protecting and guaranteeing the human rights in accordance with the principles of universality, interdependence, indivisibility and progressivity. ${ }^{152}$

\section{Content of President Peña Nieto's Legislative Bill}

This legislative bill is centered around the respect for human rights and seeks to avoid, through a quick proceeding, that the foreign person should remain in detention for a long period of time, in light of the standards established by the international instruments already mentioned.

The International Pact of Civil and Political Rights, in article 14, and the American Convention of Human Rights, in article 8, contemplate the basic guarantees of due process: the rights of presumption of innocence; the right to a defense; the right of the foreign person to be informed in his/her own language of the causes and nature of the accusation against him/her; the right to be judged by an impartial tribunal within a reasonable period of time; the right to an efficient public defense and the right to not declare against him/herself, among other.

Thus, the legislative bill formulated by the Federal Executive includes provisions whose object is to guarantee minimum conditions to foreign persons to assure the adequate protection of his/her rights, namely, the due process.

The administrative procedure of expulsion proposed by this initiative is of a sui generis nature since it preserves and respects the human rights of foreigners and, at the same time, safeguards Mexico's national security and public order. This is within the tutelage of the fundamental interests of the State and seeks the general welfare in an exercise to safeguarding them, jointly with the interests of the person.

${ }^{152}$ The third paragraph of Article 1 of the Constitution (as amended in 2011) is transcribed in footnote 62, supra. 
This legislative bill contains a respectful procedure of the human rights recognized by the Constitution that adheres to the international standards established by international organizations. This takes place since the personal notification of the initiation of the procedure takes place when the foreign person is to be informed that:

1. The reason that led to the initiation of the administrative procedure and the legal bases that support it;

2. The place, date and hour of the hearing;

3. The right of the foreign person to petition for an appropriate period of time to prepare his/her defense, provided this time does not exceed the date for the hearing to take place;

4. The right of the foreign person to provide evidence and to articulate what is pertinent to his/her rights;

5. The right of a foreign person to receive consular assistance, to have an attorney and to be in contact with a person of his/her confidence;

6. The administrative authority of the Secretariat of the Interior (Secretaría de Gobernación) that will be conducting the hearing (audiencia); and

7. The place and time of his/her detention.

In order to guarantee the right to a hearing and the right of due process, the Inter-American Court of Human Rights has pointed out that the States should, in order to provide an adequate protection when foreign person are involved, to take additional measures:

To reach its objectives, the process should recognize and resolve the factors of real inequality of those who are taken to justice... for this reason, an interpreter is to be provided to those unfamiliar with the language used during the proceedings, and for the same reason the foreigner is to be timely informed that he/she may have consular assistance.

Therefore, this legislative bill prescribes that during the conduct of the expulsion procedure the foreign person who does not speak or does not understand the Spanish language should be helped by an interpreter of his/her election; or, when this is not possible, an interpreter is to be freely provided by Secretaría de Gobernación.

\section{CONSULAR ASSISTANCE}

Once the State has detained a foreign person, its obligation is to inform that person, without delay, of his/her rights, especially those pertaining to his/her foreign status. One of said rights is to receive consular help, whose notification should be made at the time of the detention since this constitutes the basis for foreign persons to be able to exercise other rights. 
Once the foreign person is informed of his/her right to have consular assistance, the State that provides assistance to the detained person may support him/her in a number of acts leading to his/her defense, such as the right to have an attorney, to obtain evidence from his/her own country, the verification of the conditions of detention, etc.

The Consultative Opinion of the Inter American Court of Human Rights (OC-16/99) requested by Mexico, has become fundamental for the understanding of the right to consular assistance. ${ }^{153}$

The Court established that within the language of article 64.1 of the American Convention, article 36 of the Vienna Convention should be understood to contain provisions relative to human rights.

Article 36 of said Convention establishes procedures of information, notification, communication and consular assistance. In the Court's opinion, this article recognizes certain individual guarantees in favor of a foreign person who has been detained and the correlative duties upon the receiving state. ${ }^{154}$ In this regard, the Court determined that:

123. The incorporation of this right in the Vienna Convention on Consular Relations -and within the context of the respective discussions, during its drafting- demonstrates the uniform recognition that the right to information regarding consular assistance constitutes a means for the defense of the accused that affects occasionally on a decisive manner- the respect to be given to the other procedural rights. ${ }^{155}$

In symmetry with what was decided by the Court, the Federal Executive's legislative bill guarantees the right of the foreign person to keep in communication with his/her consular representation since the detention, aspect that becomes fundamental at the moment of notifying the decision of the initiation of the expulsion proceeding until its final conclusion.

\section{Legal assistance}

\footnotetext{
${ }^{153}$ See The Right to Information on Consular Assistance within the Framework of the Guarantees of the Due Process of Law. Advisory Opinion OC-16/99, Inter-Am. Ct. H.R. (ser. A) No. 16 (Oct. 1, 1999).

${ }^{154}$ Vienna Convention on Consular Relations art. 36, Apr. 24, 1963, 23 U.S.T. 3227, 500 U.N.T.S. 95.

155 The Right to Information on Consular Assistance within the Framework of the Guarantees of the Due Process of Law supra note 93 , at 123 .
} 
In 1999, the Inter American Commission of Human Rights adopted an important decision of fundamental importance regarding the expulsion of foreigners, in the case of Loren Riebe and others against Mexico. $^{156}$

In its report, the Commission recognized the right of each State to define its migratory policies and laws and, therefore, to legally decide on the entry, stay and expulsion of foreigners out of its territory. However, it also underlined that the American Convention on Human Rights establishes in article 1(1) the obligation to respect the rights and liberties recognized by it. Said obligation has been freely assumed by the Mexican State when the cited international instrument was ratified. Consequently, the exercise of the sovereignty cannot justify, in any manner, the violation of human rights since the norms of the American Convention constitute a limitation to the exercise of public power by the States.

The Inter American Commission of Human Rights determined that: the Mexican State should have guaranteed the petitioners the right of representation during the administrative procedure. This conclusion is supported not only by the guarantee of a hearing in the context of the present case but also from the viewpoint of the effective judicial tutelage. The decision of the Commission placed special emphasis in the right to be assisted by legal counsel as well as the importance of the judicial guarantees established by article 8 of the Convention.

In this regard, this legislative bill established the right of the foreign person to designate an attorney from the moment of his/her detention and the initiation of the proceedings. Otherwise, if it is not designated or when there is no legal assistance, the State shall have the obligation to provide the foreign person with an attorney.

\section{Alternative measures of detention}

All the reforms approved by the Constitutional Power in June 2011 have as their common goal to facilitate that in the internal order all the authorities of the Mexican State are to comply with the obligations assumed by the international community regarding the respect and protection of human rights.

Based on the constitutional obligation of any authority that to promote, respect, protect and guarantee human rights in accordance with the principles of universality, interdependence, indivisibility and progressivity, President Peña Nieto's legislative initiative presents alternative measures to the detention of a foreign person, pending the expulsion procedure.

\footnotetext{
156 See Riebe Star et al. v. Mexico, Case 11.610, Inter-Am. Comm'n H.R., Report No. 49/99, (1999) available at http://cidh.org/annualrep/98eng/Merits/Mexico\%2011610.htm.
} 
Thus, within the forty eight hours following the detention of a foreign person, the competent administrative authority may, taking into account the circumstances of each case, substitute said detention for other appropriate measures whose object will be to assure the proper application of the procedure.

\section{Effective recourse}

The power to expel foreign persons by the Federal Executive requires an expeditious procedure to effectively exercise said power. However, this cannot be understood under any circumstance that the resolution given in such a case may not be challenged. Accordingly, pursuant by articles 1 and 103 of the Constitution, this legislative bill establishes that, against the order of the Executive of the Union that determines the expulsion of a foreign person, the filing of an Amparo suit (Juicio de Amparo) is allowed.

\section{Other rights}

Additionally, there are other measures that may guarantee the validity of the human rights of foreign persons, to wit:

1. During the time of detention, the foreign person shall remain in the immigration installations or in the places established for that purpose;

2. In any case, the expulsion of a foreign person is to take place preferably to the country from which the foreigner is a national or a resident;

3. In no case a foreign person may be expelled to a country, whether of his/her nationality or residence, when his/her life, freedom or security are threatened or may be in danger of been subjected to torture or to other cruel, inhumane or degrading acts, or when this act places in risk his/her human rights;

4. The collective expulsion of foreign persons is prohibited;

5. To give legal security and certainty, the procedure may no exceed from the term of sixty natural days without the Executive of the Union rendering a decision, except when the procedure is suspended by order of the judicial competent authority as a result of the filing of some type of an appeal or for a reason not attributable to the authority.

Based upon the preceding reasons, the Federal Executive, in exercise of the power conferred by article 71, para. I, of the Political Constitution, submitted to the consideration of the Senate a legislative bill with a Draft decree to enact the Reglementary Act of Article 33 of the Constitution. 


\section{CONCLUSIONS}

From an international law perspective, the sovereign power of the State to protect its own territory, its nationals and its institutions against any foreign or domestic threat is unquestionable. ${ }^{157}$ Evidently, the tenor of article 33 of the Constitution emanates from this sovereign power. However, this power is neither unlimited nor discretional-contrary to the text passed by the Constitutional Congress in 1917 or to some legal opinions (Jurisprudencias) rendered by Mexico's Supreme Court. ${ }^{158}$

As a matter of fact, the excessive and abusive presidential powers recognized in these antiquarian texts appear to be somewhat of a legal aberration especially when one considers the orthodox positions Mexico tends to adopt at the international level and taking into consideration that Mexico's legal policies and positions are influenced by the geographical contiguity of this country to the United States.

The fundamental and welcome revisions made by President Calderon to articles 1 and 33 of the Constitution as a result of his "human rights reform" in 2011 represent some of the most constructive and progressive developments in recognizing, protecting and codifying the rights of foreign persons, a most sensitive topic in the relations between these two neighboring countries. Behind this "human rights reform" 159 one has to think that every year Mexico welcomes over twenty million U.S. tourists that visit that country, ${ }^{160}$ who spend some twelve billion dollars during these visits. ${ }^{161}$ On the other hand, every year more than one million undocumented Mexicans enter the United States. ${ }^{162}$

Therefore, it is of fundamental importance for Mexico to provide a fair and expeditious administrative procedure to expel, deport or extradite foreign persons; a procedure that clearly respects the human rights of foreigners in symmetry with the international standards that domestic legislation, international treaties and conventions, as well as the decisions that international courts have established on this important and delicate area.

\footnotetext{
${ }^{157}$ The Montevideo Convention of 1933 predicates that for a State to be internationally recognized as such, it is indispensable to have: a) a defined territory; b) a permanent population; c) a government; and d) the legal capacity to enter into relations with other States.

${ }^{158}$ The text of Article 33 as originally enacted in 1917 and the Supreme Court opinions appear in numeral 2, Constitutional Antecedents of Article 33, footnote 28, supra.

${ }^{159}$ See Presidential decree published in the Diario Oficial of June 10, 2011, supra note 14.

${ }^{160}$ See Office of Travel and Tourism Industries, U.S. Citizen Traffic Overseas Regions, Canada and Mexico 2013 available at http://travel.trade.gov/outreachpages/outbound.general_information.outbound_overview.html ${ }^{161}$ See Id.

${ }^{162}$ See Nwosu et al. Frequently Requested on Immigrants and Immigration in the United States, Migration Policy Institute (Apr 28, 2014) http://www.migrationpolicy.org/article/frequently-requested-statistics-immigrants-and-immigration-united-states\#4.
} 
There is no doubt that the administrative procedure established by President Peña Nieto pursuant to the Reglementary Act o54f Article 33 of the Political Constitution ${ }^{163}$ may be characterized today as one of the most fair, modern and advanced procedures for the expulsion of foreign persons at the international level.

\footnotetext{
${ }^{163}$ For unknown reasons, as of September of 2014, the proposed "Reglementary Act of Article 33 of the Political Constitution" has not been yet published in the Diario Oficial de la Federación and, as a consequence, it has not entered into force.
} 


\section{ANNEX 1: COMPARATIVE CHART OF THE BILL OF RIGHTS OF THE CONSTITUTION OF THE UNITED STATES OF AMERICA AND THE HUMAN RIGHTS IN THE POLITICAL CONSTITUTION OF MEXICO ${ }^{164}$}

\begin{tabular}{|c|c|}
\hline United States Constitution of 1787 & Individual guarantees of the Mexican Constitution of \\
1917
\end{tabular}

\section{The Bill of Rights (1791)}

\begin{tabular}{|c|c|}
\hline Amendment I: & Article 130 \\
\hline Establishment of religion & Article 24 \\
\hline Freedom of religion & Article 6 \\
\hline Right to free speech & Article 7 \\
\hline Freedom of the press & Article 9 \\
\hline $\begin{array}{c}\text { Right to peaceful assembly } \\
\text { Right to petition the Government for a redress of } \\
\text { grievances }\end{array}$ & Article 8 \\
\hline
\end{tabular}

\begin{tabular}{|c|c|}
\hline Amendment II: & \\
\hline Right to bear arms & Article 10 \\
\hline
\end{tabular}

\begin{tabular}{|c|c|}
\hline Amendment III: & Article 16, section IV \\
\hline $\begin{array}{c}\text { No Soldier shall be quartered in any house, without the } \\
\text { consent of the Owner }\end{array}$ & . \\
\hline
\end{tabular}

\begin{tabular}{|c|c|}
\hline Amendment IV: & Article 16, section I \\
\hline $\begin{array}{c}\text { The right of the people to be secure in their persons, } \\
\text { houses, papers, and effects }\end{array}$ & Article 16, section I \\
\hline The right against unreasonable searches and seizures & Article 16, section 1,2, and 3 \\
\hline Requisite of a warrant &
\end{tabular}

\begin{tabular}{|c|c|}
\hline Amendment $\mathrm{V}$ : & \\
\hline Right to a grand jury trial for a capital offense & Article 23 \\
\hline Right against double-jeopardy & Article 20, section II \\
\hline Right against self-incrimination & Article 14, section II \\
\hline $\begin{array}{c}\text { Right not to be deprived of life, liberty, or property, without } \\
\text { due process of law }\end{array}$ & Article 27 \\
\hline $\begin{array}{c}\text { No private property shall be taken for public use, without } \\
\text { just compensation }\end{array}$ & \\
\hline
\end{tabular}

\begin{tabular}{|c|c|}
\hline Amendment VI: & \\
\hline Right to a speedy and public trial & Article 20, sections VI and VIII \\
\hline Right to a jury trial & Article 20, section VI \\
\hline
\end{tabular}

${ }^{164}$ This chart is reproduced from the book by James F. Smith, supra note 9, at 108-110. 


\begin{tabular}{|c|c|}
\hline $\begin{array}{c}\text { Right to be informed of the nature and cause of the } \\
\text { accusation }\end{array}$ & Article 20, section III \\
\hline Right to be confronted with the witnesses against him & Article 20, section IV \\
\hline $\begin{array}{c}\text { Right to have compulsory process for obtaining witnesses } \\
\text { in his favor }\end{array}$ & Article 20, section V \\
\hline Right to have the assistance of counsel for his defense & Article 20, section IX \\
\hline
\end{tabular}

\begin{tabular}{|c|c|}
\hline Amendment VII: & \\
\hline The right of trial by jury shall be preserved & ${ }^{* *}$ \\
\hline
\end{tabular}

\begin{tabular}{|c|c|}
\hline Amendment VIII: & \\
\hline Right against excessive bail and fines & Article 20, section I \\
\hline Right against cruel and unusual punishments & Article 22 \\
\hline
\end{tabular}

\begin{tabular}{|c|c|}
\hline Amendment IX: & Article 1 \\
\hline $\begin{array}{c}\text { The enumeration in the Constitution, of certain rights, shall } \\
\text { not be construed to deny or disparage others retained by } \\
\text { the people }\end{array}$ & \\
\hline
\end{tabular}

\begin{tabular}{|c|c|}
\hline Amendment X: & Article 124 \\
\hline $\begin{array}{c}\text { The powers not delegated to the United States by the } \\
\text { Constitution, nor prohibited by it to the States, are reserved } \\
\text { to the States respectively, or to the people }\end{array}$ & \\
\hline
\end{tabular}

\section{Reconstruction Amendments (1865-1868)}

\begin{tabular}{|c|c|}
\hline Amendment XIII: & \\
\hline Abolition of slavery & Article 2 \\
\hline \multicolumn{2}{|l|}{ Amendment XIV: } \\
\hline Citizenship & Article 34 \\
\hline Due process of the law & Article 14 \\
\hline Equal Protection of the law & Article $1,2,4,12$, and 13 \\
\hline Amendment XV: & \\
\hline Suffrage; political franchise & Articles 35 and 36 \\
\hline
\end{tabular}




\section{ANNEX 2: TEXT OF PRESIDENT PEÑA NIETO'S DRAFT DECREE TO ENACT THE REGLEMENTARY ACT OF ARTICLE 33 OF THE POLITICAL CONSTITUTION OF THE UNITED MEXICAN STATES.}

\section{Chapter One}

\section{General Provisions}

Article 1. The present statute is a Reglementary Act of article 33 of the Political Constitution of the United Mexican States, whose object is to regulate the procedure through which the Executive of the Union may exercise its power to expel foreign persons from the national territory, understanding for said persons those that not being Mexican, neither by birth nor by naturalization, and who having been legally found within the national territory, incur in any of the situations contemplated by this statute, whereby the human rights recognized by this constitution and by the international treaties to which the Mexican State is a party are to be respected.

The present statute is not to apply to foreign persons who are within the national territory and whom, according to international law, enjoy privileges and immunities. The provisions of this statute are of public order and obligatory throughout the national territory.

Article 2. The application of this statute, as well as the conduct and compliance of the procedures hereby established correspond to the Executive of the Union through the Secretariat of the Interior (Secretaría de Gobernación).

Article 3. For the application of this Act, the Secretariat of the Interior (Segob) may request the assistance of the dependencies or entities of the Federal Public Administration and of the federal entities (States) and municipalities, within the ambit of their competence.

The institutions of Public Security shall provide the necessary assistance, within the ambit of their competence, for the compliance of this Act.

Article 4. The subjects of the procedure of expulsion are those foreign persons who pose a threat to the national security or to the public order and security in accordance with the pertinent legislation on these matters and also under the terms of article 33 of the Political Constitution of the United Mexican States.

Article 5. The information relating to the expulsion of foreign persons shall be confidential and reserved, pursuant to the terms of the Federal Act of Transparency and Access to Public Governmental Information (Ley Federal de Transparencia y Acceso a la Información Pública Gubernamental). 


\section{Second Chapter}

\section{Procedure}

Article 6. Foreign persons may be expelled from the national territory, once the hearing to which article 33 of the Constitution refers to has already taken place.

The procedure of expulsion established by this Act may not exceed sixty natural days. Once this term has elapsed without the Executive of the Union rendering his determination, the procedure is deemed to be finished and the detention and cautionary measures that may have been imposed are to be lifted, unless the procedure has been suspended by order of the competent judicial authority as a result of the filing of some means of challenging it (Medio de impugnación) or for other cause not imputable to the authority.

Article 7. During the conduct of the expulsion procedure, the foreign person who does not speak nor understand the Spanish language shall be assisted, from the very beginning, by a particular interpreter of his/her election; in the absence of it, said interpreter shall be provided by the Secretariat of the Interior (Secretaría de Gobernación).

Article 8 . Any authority may inform the Secretariat of the Interior of any acts that may give place to the initiation of the expulsion procedure.

Article 9. In the case that two or more foreign persons have jointly incurred in the same cause leading to the initiation of the procedure, this procedure shall take place in an individual manner.

Article 10. When the Secretariat of the Interior (Secretaría de Gobernación) has vague information (indicios) that the foreign person has engaged in some of the acts or omissions to which Article 4 of this Act refers to, Segob shall collect pertinent information from the competent authorities.

Article 11. Based on the collected information, the Secretariat of the Interior (Secretaría de Gobernación) may either discard the file or notify the foreign person of the initiation of the proceedings.

Article 12. The notification of the initiation of the proceedings shall be done in writing and in a personal manner, during which the foreign person is to be informed of his/her right to have a hearing, attaching a copy of the decision to which article 13 of this Act refers to.

This notification may be served in any place where the foreign person may be found. For purposes of this notification any days and hours are deemed to be valid (Hábiles).

If the foreign person refuses to receive the notification, the server (Notificador) shall report this fact in the corresponding minute (Acta), before the presence of two witnesses. In any case, the minute shall refer that the foreign person was duly informed of his/her right to have a hearing (Derecho de audiencia). 
Article 13. The court's decision (Acuerdo) informing about the initiation of the expulsion procedure shall contain:

1. The reason whereby the initiation of the proceedings is taking place and the grounds (Fundamentos) supporting it;

2. The place, date and hour of the hearing, which is to take place between three and ten natural days following the date of the initiation of the proceedings;

3. The right of a foreign person to request a period of time needed to prepare his/her defense, within the period established to set the date of the hearing;

4. The right of the foreign person to offer evidence and manifest what may support his/her case;

5. The right of a foreign person to receive consular attention, to have an attorney and to maintain communication with a person of his/her confidence;

6. The administrative authority of the Secretariat of the Interior (Secretaría de Gobernación) that shall be conducting the hearing;

7. The place and time of his/her detention that may not exceed the period of time prescribed in article 6 of this Act.

\section{Third Chapter}

\section{Of the Detention and Cautionary Measures}

Article 14. The foreign person shall be detained at the time when he/she is served notice of the initiation of the proceedings established by this Act, and shall remain in the immigration installations or places established for that purpose by the Secretariat of the Interior (Secretaría de Gobernación).

Article 15. Within forty-eight hours following the detention, the competent administrative authority of the Secretariat of the Interior, may substitute the detention for other cautionary measures whose object is to assure the conduct of the expulsion proceedings and avoid that the foreign person may incur or persist in the situations established by article 4 of this Act.

The lack of compliance of the cautionary measures (Medidas cautelares) imposed to the foreign person will lead to the ordering of his/her detention until the end of the proceedings under the terms established by this Act.

The Secretariat of the Interior shall impose one or more of the following cautionary measures (medidas cautelares): 
1. To give an economic guarantee which shall consist in a cash deposit in a financial institution or through a bond, for the amount established by the competent authority of the Secretariat of the Interior;

2. Prohibition to abandon a determined geographical demarcation;

3. Vigilance by the authority designated for that purpose;

4. Obligation to show up periodically before the authority that is conducting the proceedings;

5. The placement of electronic devices, causing no violence or injury to the dignity or physical integrity of the foreign person; and

6. Prohibition or restriction to attend certain meetings, visit certain places or communicating with specific persons, when these are familiar with the facts that led to the initiation of the proceedings;

The detention shall be maintained when the administrative authority considers that the cautionary measures to which the previous paragraphs refer to are not sufficient to guarantee that the foreign person is to abstain to become involved with the facts to which article 4 of this Act refers to, as well as when necessary for the proper conduct of the proceedings.

Article 16. In the determination of the cautionary measures the Secretariat of the Interior should consider the following:

1. The circumstances of the facts committed by the foreign person that fits some of the situations to which article 4 of this Act refers to that led to the initiation of the proceedings;

2. The proportionality of the measures in relation with the goals sought;

3. The particular circumstances of the foreign person; and

4. Other data that may be relevant for the determination of the measures.

Article 17. Since the moment of detention the foreign person shall be informed of his/her right to receive consular assistance, and all the facilities shall be given to maintain communication with his/her consular representatives.

The Secretariat of the Interior shall immediately notify the diplomatic or consular representation of the detention of the foreign person, and shall inform of this fact to the Secretariat of Foreign Relations (Secretaría de Relaciones Exteriores).

Article 18. The detained foreign person shall have the right to maintain communication with a person of his/her confidence and with his/her attorney.

Article 19. The foreign person shall designate, since the moment of his/her detention, a particular attorney (Abogado particular). When there is no attorney and no legal assistance, the Secretariat of the Interior shall have the obligation to provide him/her with an attorney. 
For this purpose, the Secretariat of the Interior shall enter into agreements with the Federal Institute of Public Defenders (Instituto Federal de Defensoría Pública) or other institutions public or private.

\section{Fourth Chapter}

Of the Hearing and the Resolution of the Procedure

Article 20. The competent authorities that intervene in the expulsion procedure to which this Act refers to and the foreign persons subject to same procedure, shall assume the burden of proof with regard to their affirmations.

Article 21. The proofs offered by the foreign person shall be presented at the hearing, for which he/she shall have the legal assistance of his/her attorney or of the attorney provided by the Secretariat of the Interior.

Article 22. The hearing shall take place the day and hour indicated before the competent instance of the Secretariat of the Interior.

Article 23. At the hearing all the evidence (Pruebas) shall be submitted, save for those that because of their own nature may not be rendered, in which case the hearing may be postponed, for one time only, with the goal of preparing their presentation, without having to exceed the period established by article 6 of this Act.

In any case, the respective minute (Acta) shall be written.

Article 24. Once the evidence is presented, at the same hearing, the foreign person may present his/her final arguments (alegatos) in an oral manner, in which case a summary of said arguments shall be transcribed in the act of the hearing, or a term of forty eight hours shall be given to submit them in writing.

Later on, a notation (acuerdo) shall be dictated closing this phase of the final arguments.

Article 25. The Secretariat of the Interior may declare the closing of the proceedings (sobreseimiento) in case the foreign person requests to be taken outside the national territory. In this case, he/she shall declare his/her consent to the Secretariat of the Interior that he/she will be prevented from reentering the national territory, pursuant to article 31 of this Act.

The procedure shall also be concluded in any other case in which the procedure be left without a cause (el procedimiento quede sin materia) before the term to which article 6 of this Act is concluded.

Article 26. Once the hearing is concluded, the Secretariat of the Interior shall obtain the opinion of the Secretariat of Foreign Relations and may request the opinion of other authorities that may consider pertinent.

Article 27. The Secretariat of the Interior may resolve in any of these manners:

1. To declare that there are sufficient elements to expel the foreign person from the national territory;

2. To declare that there are no sufficient elements to expel the foreign person from the national territory. 
Article 28. In the cases of paragraph II of the previous article, the procedure is to be considered completed in a definitive manner and the cautionary measures should be lifted.

Article 29. If in the resolution issued it is considered that there are sufficient elements for the expulsion, the Secretariat of the Interior shall submit to the consideration of the Executive of the Union the corresponding file, who is to determine whether to exercise of the faculty conferred upon by article 33 of the Political Constitution of the United Mexican States.

Article 30. If the Executive of the Union may deem appropriate the expulsion of the foreign person, he/she shall sign the corresponding agreement that will have the backing (Refrendo) of the Secretariats of the Interior and of Foreign Relations. This agreement is to be served upon the foreign person within the period of time established by article 6 of the Act.

\section{Fifth Chapter}

\section{Of the Execution of the Resolution}

Article 31. The expulsion shall be conducted (ejecutada) by the Secretariat of the Interior through the National Immigration Institute (Instituto Nacional de Migración).

The expulsion of a foreign person, under the terms of this Act, also implies the prohibition to re-enter into the national territory. The Secretariat of the Interior may only authorize the re-entry into the national territory in accordance with the applicable legal provisions, when the circumstances that led to the expulsion had disappeared.

Article 32. The expulsion of the foreign person shall be preferably to the country from which said person is a national or a resident.

Article 33. In no case the foreign person may be expelled to a country, whether or not of his/her nationality or residency, where his/her life, liberty and security have been threatened or may be in danger of been subjected to torture or other cruel, inhumane or degrading acts, or when this act places in risk his/her human rights.

Article 34. When the expulsion of the national territory is applied to a foreign person who is subject to a criminal proceeding or has been sentenced for a crime that merits incarceration (pena privativa de libertad) and is serving an imprisonment sanction, the decision to expel shall be implemented once the proceeding is concluded or the punishment is completed, as appropriate. 


\section{TRANSITORY ARTICLES}

\section{First}

The present decree shall enter into force the day following its publication in the Official Gazette of the Federation (Diario Oficial de la Federación).

\section{Second}

The expenditures that shall be generated as a result of the entering into force of this Act shall be covered from the authorized budget of the Secretariats of the Interior and of Foreign Relations, so no budgetary enlargement will be necessary and their regular budgets shall not be increased for neither the current nor for subsequent fiscal exercises. ${ }^{165}$

\section{EXPULSÃO DE ESTRANGEIROS NO MÉXICO: UM COMENTÁRIO SOBRE O "NOVO PROCEDIMENTO ADMINISTRATIVO DE EXCLUSÃO" PROPOSTO PELO PRESIDENTE ENRIQUE PEÑA NIETO SOB O FUNDAMENTO DO ATO REGULAMENTAR DO ARTIGO 33 DA CONSTITUIÇÃO}

\section{Resumo}

Este estudo problematiza a expulsão de estrangeiros no México: um comentário sobre o Novo "Procedimento Administrativo de Exclusão" proposto pelo presidente Enrique Peña Nieto ao abrigo da Reglementary Act do artigo 33 da Constituição.

A Constituição do México foi profundamente influenciada pela Constituição dos Estados Unidos, e a maioria das "garantias individuais" são derivadas da Constituição dos EUA. Durante os séculos XIX e XX, o México foi deferente ao uso e significado filosófico da expressão legal Garantías Individuales. Isso explica por que o artigo 1 no Capítulo I, da Constituição - formada por 29 artigos- foi intitulado: As garantias individuais.

No entanto, a longa deferência legal dada ao termo "garantias individuais" foi um pouco abandonado em 2011, quando o então presidente do México, Felipe Calderón Hinojosa, decidiu mudar o nome do Capítulo I da Constituição por meio de um decreto publicado no Diario Oficial de la Federación (DOF), em 10 de junho de 2011. Este decreto, inter alia, substituído o termo tradicional de "Garantías Individuales" para o novo conceito de "Direitos Humanos".

Como resultado as migrações transatlânticas e intercontinentais são um exemplo particularmente útil para ilustrar a importância do contexto internacional no desenvolvimento da lei por causa das diferentes maneiras como cada órgão governamental respondeu às pressões sociais. Este estudo mostra como as múltiplas e complexas redes

Source:
1/assets/documentos/Ley_Reglamentaria_art.33_CPEUM.pdf

http://senado.gob.mx/sgsp/gaceta/62/2/2013-10-22 
reguladoras intergovernamentais em matéria de mobilidade dessa força de trabalho desenvolvidas em um contexto internacional, não apenas no âmbito do desenvolvimento dos sistemas jurídicos nacionais isolados.

As revisões fundamentais e de boas-vindas feito pelo presidente Calderon aos artigos 1 e 33 da Constituição, como resultado de sua "reforma de direitos humanos" em 2011 representam alguns dos desenvolvimentos mais construtivos e progressistas, em reconhecer, proteger e codificar os direitos das pessoas estrangeiras, um tema mais sensível nas relações entre estes dois países vizinhos. Por trás dessa "reforma de direitos humanos" tem de se pensar que todos os anos, acolhe o México mais de vinte milhões de turistas norte-americanos que visitam esse país, que gastam cerca de doze mil milhões de dólares durante essas visitas. Por outro lado, a cada ano mais de um milhão de mexicanos sem documentos tentam entrar nos Estados Unidos.

Portanto, é de fundamental importância para o México fornecer um procedimento administrativo equitativo e rápido para expulsar, deportar ou extraditar pessoas estrangeiras; um procedimento que respeite claramente os direitos humanos dos estrangeiros em simetria com as normas internacionais de que a legislação nacional, os tratados e convenções internacionais, bem como as decisões que os tribunais internacionais estabeleceram nesta área importante e delicada.

Palavras-chave: Expulsão de estrangeiros. México. Procedimento Administrativo de Exclusão. Reglementary Act do artigo 33 da Constituição. Reforma dos direitos humanos.

\section{REFERÊNCIAS}

AGENDA DE AMPARO 2014. Editorial ISEF, México, D.F. (2014) at p. 1.

AGENDA DE LA ADMINISTRACION PUBLICA FEDERAL 2013. Published by Ediciones Fiscales ISEF, 26th edition, México, D.F., January 2013

ALEINIKOFF, T. Alexander MARTIN David and MOTOMURA. Hiroshi. Immigration And Nationality Laws OfThe United States, Thomson West (2007), pp.1-343.

ARCHIBOLD, Randal C. A Proposal to Address Rights Abuse in Mexico, N.Y, Times, Oct. 192010

BERNAL. Beatriz; México y Cuba: Caminos Divergentes en materia de Expulsión de Extranjeros. Anuario Mexicano de Historia del derecho. México, UNAM, 1996.

BOSWELL. Richard A. Essentials Of Immigration Law. American Immigration Lawyers Association (2006).

BRINGAS, Enrique Sánchez; Los Derechos Humanos En La Constitución Y En Los Tratados Internacionales. Porrúa, México (2001).

BULLÉ, Victor Martínez; La Declaración de los Derechos del Hombre y del Ciudadano de 1789, Bicentenario de la Revolución Francesa. México, UNAM (1991).

CARBONELL , M. and SALAZAR. P.; La Reforma Constitucional de Derechos Humanos. Porrúa/UNAM (2013).

COUNCIL OF EUROPE, EUROPEAN CONVENTION FOR THE PROTECTION OF HUMAN RIGHTS AND FUNDAMENTAL FREEDOMS, as amended by Protocols Nos. 11 and 14, 4 November 1950, 
ETS

5 ,

available

at

http://en.wikisource.org/wiki/European_Convention_for_the_Protection_of_Human_Rights_and_Funda mental_Freedoms

COMISIÓN DE DERECHOS HUMANOS DEL DISTRITO FEDERAL; Las Reformas Constitucionales en Materia de Derechos Humanos. (2012).

CONSTITUCIÓN POLÍTICA DE LOS ESTADOS UNIDOS MEXICANOS, editorial ISEF Agenda de Amparo 2104.

DICCIONARIO JURÍDICO. Instituto de Investigaciones Jurídicas de la UNAM, México, D.F. (2004)

DECRETO POR EL QUE SE MODIFICA LA DENOMINACIÓN DEL CAPÍTULO I DEL TÍTULO PRIMERO Y REFORMA DIVERSOS ARTÍCULOS DE LA CONSTITUCIÓN POLÍTICA DE LOS ESTADOS UNIDOS MEXICANOS, Diario Oficial [DO], 10 de Junio de 2014 available at http://dof.gob.mx/nota_detalle.php?codigo=5194486\&fecha=10/06/2011.

GUERRA, Elisa Speckman; El Porfirato, Nueva Historia minima de México 192 (2004).

GAITHER, Roscoe B.; Expropriation in Mexico: The Facts and the Law (NY: William Morrow and Co., 1940)

GONZÁEZ, Guadalupe and PELLICER. Olga; La Política Exterior De México . Itam-Siglo XXI, 2013.

La Política Exterior De México. Metas y Obstáculos. ITAM/Siglo XXI Editores (2013);

HAWLEY, Chris; Activists blast Mexico's immigration law, USA Today, (Jan. 16, 2015), http://usatoday30.usatoday.com/news/world/2010-05-25-mexico-migrants_N.htm.

INICIATIVA DEL DÍA, 14 de Agosto de 2013, Senado de la Republica, available at http:/www.senado.gob.mx/?ver=sp\&mn=2\&id=42998.

IMPACT IN 47 COUNTRIES, EUROPEAN CONVENTION ON HUMAN RIGHTS, (Jan. 17, 2015, 3:38PM), http://human-rights-convention.org/impact-of-the-european-convention-on-human-rights/ (listing European members of the Convention).

JUÁREZ, Carlos Castilla; Un nuevo panorama constitucional para el derecho internacional de los derechos humanos en México, Estudios Constitucionales. Año 9, No. 2, Universidad de Talca, 2011.

JAYNE. Catherine E.; Oil, War and Anglo-American Relations. Greenwood Press (2001).

KURZBAN. Ira J.; Brief History of Immigration Laws. IMMIGRATION LAW SOURCEBOOK (2004), pp. 120.

LEY DE MIGRACIÓN, Diario Oficial de la Federación [DO], 6 de Julio de 2013; Ley General de Población, Diario Oficial de la Federación [DO], 7 de Enero de 1974, available at http://www.diputados.gob.mx/LeyesBiblio/pdf/140.pdf.

LEY DE INVERSION EXTRANJERA, Diario Oficial de la Federación [DO], 27 de Diciembre de 1993, available at http://www.sre.gob.mx/images/stories/marconormativodoc/leyes/leyinver.pdf. 
LEY FEDERAL DEL TURISMO, Diario Oficial de la Federacion, [DO], Diario Oficial de la Federación, 17 de Junio de 2009, available at http://secturbcs.gob.mx/wpcontent/uploads/2014/07/LEY_GENERAL_DE_TURISMO.pdf.

LEY GENERAL DE SALUD, Diario Oficial de la Federacion [DO], 7 de febrero de 1984, available at http://www.diputados.gob.mx/LeyesBiblio/pdf/142_191214.pdf.

LEY DE MIGRACIÓN, published in the Diario Oficial de la Federación (DOF) of July 6, 2013.

MEYER M.; The Course of Mexican History. Oxford University Press (1999).

MCKENZIE JOHNSTONE, Henry. Mission to Mexico: A Tale of British Diplomacy in the 1820's. New York: Saint Martin Press, 1992.

MEYER, Lorenzo; Mexico and the United States in the Oil Controversy, 1918-1942 (Austin, U. Texas Press) 1972.

MIGRATION POLICY INSTITUTE, Nwosu et al. Frequently Requested on Immigrants and Immigration in the United States, http://www.migrationpolicy.org/article/frequently-requested-statistics-immigrants-andimmigration-united-states\#4. (Apr 28, 2014).

OFFICE OF TRAVEL AND TOURISM INDUSTRIES, U.S. Citizen Traffic Overseas Regions, Canada and Mexico 2013. http://travel.trade.gov/outreachpages/outbound.general_information.outbound_overview.html.

PLETCHER, David M; The Diplomacy of Annexation: Texas, Oregon and the Mexican War (1973.

RAMÍREZ. Manuel Becerra; El Artículo 33 Constitucional en el Siglo XXI. Biblioteca Jurídica Virtual del IIJ de la $\operatorname{UNAM}(2013)$.

ROBERTSON, William S.; French Intervention in Mexico in 1838. Hispanic american historical review, 24 (1944).

SMITH, James F; Introducción, Derecho Constitucional Comparado México-Estados Unidos. UNAM, México (1990).

SMITH , P. and Selee, A. (Eds.); Mexico And The United States (Lynne Rienner Publishers) 2013.

SENATE'S LEGISLATIVE BILL OF 14 AUGUST 2013. Segundo Receso, Primer Año de Ejercicio, LXII Legislatura, Miércoles 14 de Agosto de 2013, Gaceta:29. Eighteen Senators formulated and supported this bill that may be found at: http://www.senado.gob.mx/?ver=sp\&mn=2\&sm=2\&id=42998.

SENATE'S LEGISLATIVE BILL OF 14 AUGUST 2013, Senado De La Republica, available at http://www.senado.gob.mx/?ver=sp\&mn=2\&sm=2\&id=42998.

THE ADMINISTRATION AND DEVELOPMENT OF IMMIGRATION LAW AND IMMIGRANTS' RIGHTS UNDER THE CONSTITUTION. Washington, D.C. (2006). 
THE RIGHT TO INFORMATION ON CONSULAR ASSISTANCE WITHIN THE FRAMEWORK OF THE GUARANTEES OF THE DUE PROCESS OF LAW. Advisory Opinion OC-16/99, Inter-Am. Ct. H.R. (ser. A) No. 16 (Oct. 1, 1999).

THE TRUE FACTS ABOUT THE EXPROPRIATION OF THE OIL COMPANIES' PROPERTIES IN MEXICO. Government of Mexico, Mexico City, 1940.

ULLOA. Berta La Lucha; Armada (1911-1920). Historia General de México (Versión 2000).

UGARTE, Pedro Salazar; OCHOA, José Luis Caballero; VÁZQUEZ, Luis Daniel, “El Principio Pro-Persona” at La Reforma Constitucional sobre Derechos Humanos. Una Guía Conceptual by Senado de la República, Instituto Belisario Domínguez, México, D.F., 2014.

UGARTE, Pedro Salazar, Carbonell, Miguel; La Reforma Constitucional de derechos Humanos, Porrúa-UNAM, Mexico, 2013.

VÁZQUZ, Josefina Zoraida; El Establecimiento de México Independiente(1821-1848), Historia de México (Girseda Von Wohser Ed. 2010).

De la Independencia a la Consolidación Republicana (From the Independence to the Republican Consolidation) in Nueva Historia Mínima De México. El Colegio de México (2004), pp. 158-164.

VARGAS, Jorge A. Acquisition of Real Estate. Mexican Law for the American Lawyer (Carolina Academic Press), (2009)

Is the International Boundary between the United States and Mexico Wrongly Demarcated? 30 California Western International Law Journal (Spring 2000, No. 2)

VIENNA CONVENTION ON CONSULAR RELATIONS; art. 36, Apr. 24, 1963

WOBESER, Gisela Von; Historia de México, FCE/SEP (2010)

WEISSBRODT, David; DANIELSON. Laura; History of U.S. Immigration Law and Policy. Immigration Law And Procedure. West Nutshell Series (2010).

ZORRILLA, Luis G.; Historia de las Relaciones entre Mexico y los Estados Unidos de América, 1800-1958, (1977).

Trabalho enviado em 28 de abril de 2015.

Aceito em 24 de maio de 2015. 